OPEN ACCESS

Edited by:

Xin $\mathrm{Li}$

University of British Columbia, Canada

Reviewed by:

Li-Jun Ma,

University of Massachusetts Amherst,

USA

Jacqueline Monaghan,

Queen's University, Canada

Amir Sharon,

Tel Aviv University, Israel

*Correspondence:

W. G. Dilantha Fernando

dilantha.fernando@umanitoba.ca

Specialty section:

This article was submitted to

Plant Biotic Interactions,

a section of the journa

Frontiers in Microbiology

Received: 31 January 2016 Accepted: 11 April 2016

Published: 27 April 2016

Citation:

Selin C, de Kievit TR, Belmonte MF and Fernando WGD (2016) Elucidating the Role of Effectors in Plant-Fungal Interactions: Progress and

Challenges. Front. Microbiol. 7:600. doi: 10.3389/fmich.2016.00600

\section{Elucidating the Role of Effectors in Plant-Fungal Interactions: Progress and Challenges}

\author{
Carrie Selin ${ }^{1}$, Teresa R. de Kievit ${ }^{2}$, Mark F. Belmonte ${ }^{3}$ and W. G. Dilantha Fernando ${ }^{1 *}$ \\ ${ }^{1}$ Department of Plant Science, University of Manitoba, Winnipeg, MB, Canada, ${ }^{2}$ Department of Microbiology, University of \\ Manitoba, Winnipeg, MB, Canada, ${ }^{3}$ Department of Biological Sciences, University of Manitoba, Winnipeg, MB, Canada
}

Pathogenic fungi have diverse growth lifestyles that support fungal colonization on plants. Successful colonization and infection for all lifestyles depends upon the ability to modify living host plants to sequester the necessary nutrients required for growth and reproduction. Secretion of virulence determinants referred to as "effectors" is assumed to be the key governing factor that determines host infection and colonization. Effector proteins are capable of suppressing plant defense responses and alter plant physiology to accommodate fungal invaders. This review focuses on effector molecules of biotrophic and hemibiotrophic plant pathogenic fungi, and the mechanism required for the release and uptake of effector molecules by the fungi and plant cells, respectively. We also place emphasis on the discovery of effectors, difficulties associated with predicting the effector repertoire, and fungal genomic features that have helped promote effector diversity leading to fungal evolution. We discuss the role of specific effectors found in biotrophic and hemibiotrophic fungi and examine how CRISPR/Cas9 technology may provide a new avenue for accelerating our ability in the discovery of fungal effector function.

Keywords: effectors, biotrophs, necrotrophs, hemibiotrophs, plant pathogen interactions, plant resistance

\section{INTRODUCTION}

Fungal plant pathogens are economically important due to the threat they pose to the production and yield of agricultural crops. It has been estimated that global agricultural production suffers an average annual loss of 15\% due to plant diseases (Oerke, 2006; Lo Presti et al., 2015; Schwessinger et al., 2015). To reduce and/or prevent fungal plant diseases, farmers depend on resistant crop cultivars or fungicide treatments. Furthermore, current agricultural cropping strategies rely primarily on the rotation of one cropping genotype within large areas of land, promoting the selection of fungal isolates capable of overcoming crop resistance. Such farming practices impose the need for continuous development and introduction of new genetic resistance traits into crop plants through breeding (Lo Presti et al., 2015).

The lifestyles of plant pathogenic fungi are highly diverse and utilize distinct strategies to interact with the host plant. For example, necrotrophic fungi infect and kill host tissue and extract nutrients from dead host cells. Biotrophic fungi colonize living host tissue and obtain nutrients from living tissue; whereas hemibiotrophic fungi display two phases during the infection process; first is an initial biotrophic phase followed by a necrotrophic stage (Lo Presti et al., 2015). Despite the diversity among these lifestyles, all fungi that colonize plants are recognized by the plant innate immune system, which elicits a host defense response. The innate immune perception triggers both local 
and systemic reactions, allowing a plant to respond to pathogen attack in a quick and localized manner over an extended period of time (Schwessinger and Ronald, 2012). For this reason, the plant utilizes a two-tier innate immune response that involves a combination of localized plasma membrane and intracellular receptors (Jones and Dangl, 2006; Dodds and Rathjen, 2010; Asai and Shirasu, 2015).

The initial tier of the innate response is generally triggered by molecules essential to the pathogen and cannot be modified without significant loss of viability. These molecules include abundant bacterial proteins, elongation factors $\mathrm{Tu}(\mathrm{Ef}-\mathrm{Tu})$, flagellin, and fungal cell wall components such as polysaccharides and chitin (Win et al., 2012; Newman et al., 2013). These components are usually exposed and are referred to as pathogenassociated molecular patterns (PAMPs) and microbe-a associated molecular patterns (MAMPs). During infection, PAMPs present within the plant apoplast and are recognized by membranelocalized pattern recognition receptors (PRRs), which initiates the first reaction of defense called PAMP-triggered immunity (PTI) (Jones and Dangl, 2006; Koeck et al., 2011). In Arabidopsis thaliana, the flagellin receptor, FLS2, a leucine rich repeat (LRR) receptor-like kinase, recognizes the highly conserved $\mathrm{N}$-terminus of bacterial flagellin (flg22) and activates the MAP kinase pathway to induce expression of defense response genes (Gomez-Gomez and Boller, 2002). In addition, changes in hormone biosynthesis and plant cell reinforcement by callose deposition have been shown to occur upon PRR activation (Macho and Zipfel, 2014). Interestingly, oligomers of fungal chitin are recognized by the LysM-RLK (receptor-like kinase) AtCERK1 A. thaliana receptor via three extracellular domains (Miya et al., 2007; Liu et al., 2012). The resulting chitin-induced homodimerization of CERK1 has been shown to be essential for the activation of downstream signaling (Liu et al., 2012). In a recent study, however, a lysin motif receptor kinase (LYK) termed AtLYK5 was shown to be the primary chitin receptor, not AtCERK1 (Cao et al., 2014). Interestingly, the AtLYK5 appears to directly interact with AtCERK1, forming a chitin inducible complex to induce plant defense (Cao et al., 2014). Similary in rice, the CEBiP, a LysM-receptor like-protein (RLP), was also shown to directly bind chitin elicitors and interact with OsCERK1, a homolog of AtCERK1, in a chitin-dependent manner (Kaku et al., 2006; Shinya et al., 2012). Studies have shown that reduced expression of either CEBiP or rice CERK1 in RNA interference (RNAi) lines results in an impaired response to chitin elicitors (Kaku et al., 2006; Shimizu et al., 2010). This suggests that both of these molecules are required for chitin signaling in rice.

To successfully facilitate infection, or to establish compatible interactions that lead to proliferation, fungi must be able to counteract PTI. To suppress the immune response and manipulate host cell physiology, plant pathogens secrete effector proteins (Stergiopoulos and de Wit, 2009; de Jonge et al., 2011; Giraldo and Valent, 2013). Although these secreted proteins are key players in suppressing PTI, they are also recognized by the plant surveillance system, which in turn triggers the second tier of immune response termed effector triggered immunity (ETI). Effectors that elicit an ETI response can be recognized by plant resistance proteins ( $R$ proteins), which are intracellular nucleotide-binding leucine rich repeat (NLR) receptors (Cui et al., 2015). Recognition of effector proteins via NLR receptors occurs through direct (receptor-mediated binding) or indirect (accessory protein-mediated) interactions (Dodds and Rathjen, 2010; Cui et al., 2015). Activation of ETI results in disease resistance and is usually associated with a hypersensitive cell death response (HR) localized at the infection site (Jones and Dangl, 2006). The strong HR response and resulting phenotype is a product of what is termed host specific gene-for-gene interactions, where an effector, coined Avr (avirulence), is recognized by the cognate R-protein produced by the host plant (Dodds and Rathjen, 2010). To date, $\sim 83$ effector proteins have been cloned and characterized from crop-infecting fungi and oomycetes (Table 1); 43 of which are encoded by Avr genes. In addition, a majority of cognate plant R-proteins associated with a specific Avr have also been identified (Stergiopoulos and de Wit, 2009; Gururania et al., 2012; Ali et al., 2014). Elucidation of the role of Avr effectors in virulence and the underlying mechanisms involved remains a challenge. Nevertheless, recent research is beginning to reveal the function of increasing numbers of fungal effectors bringing forward new technologies that may help address some of these knowledge gaps and improve our understanding in plant-pathogen interactions.

In this review we focus on effector molecules of biotrophic and hemibiotrophic fungi, taking a close look at the mechanisms involved in release and uptake of effector molecules by the fungi and plant cells, respectively. We place emphasis on how effectors were discovered, and difficulties associated with determining the effector repertoire. We then discuss the role of specific effectors found in biotrophic and hemibiotrophic fungi and look at how new technology for generating direct mutations may provide a new avenue for elucidating the function of fungal effector proteins.

\section{EFFECTOR DELIVERY MECHANISMS OF FUNGAL PATHOGENS}

Effectors can be defined as molecules that alter host cell structure and function, facilitating infection (virulence factors or toxins) and/or triggering defense responses (avirulence factors: Avr). These proteins can be grouped into two classes based on their target sites in the host plant (Kamoun, 2006, 2007). Apoplastic effectors are secreted into the plant apoplast, where they interact with extracellular targets and surface receptors, whereas cytoplasmic effectors are translocated inside the plant cell (Djamei et al., 2011; Dong et al., 2011; Yaeno et al., 2011; Park et al., 2012). Regardless of the effector type, efficient delivery of effectors to the plant is required for the infection process. Since pathogenic fungi have developed distinct lifestyles, they have also established diverse effector delivery systems upon infection. Biotrophic and hemibiotrophic fungal pathogens feed and live on living host cells, and secrete effectors that are targeted for the host apoplast or cytoplasm using specialized infection structures such as appressoria or haustoria (Kemen et al., 2005; Catanzariti et al., 2006; Rafiqi et al., 2010; 
TABLE 1 | Effectors of well-characterized biotrophic and hemibiotrophic plant pathogenic fungi ${ }^{\mathrm{a}}$ and oomycetes that have been cloned and studied to date (Excludes toxins).

\begin{tabular}{|c|c|c|c|c|c|c|c|}
\hline Effector Protein ${ }^{b}$ & Length ${ }^{c}$ & $\begin{array}{l}\text { N-terminal } \\
\text { signal motif or } \\
\text { conserved } \\
\text { domains }\end{array}$ & $\begin{array}{l}\text { Localization in } \\
\text { planta }\end{array}$ & Expression & $\begin{array}{l}\text { R-protein } \\
\text { association; role } \\
\text { in virulence }\end{array}$ & $\begin{array}{l}\text { Genomic } \\
\text { location }\end{array}$ & References \\
\hline \multicolumn{8}{|c|}{ Blumeria graminis f. sp hordei (biotroph; host: barley) } \\
\hline AvrA10 & 286 & Unknown & $\begin{array}{l}\text { Cytoplasm } \\
\text { (predicted) }\end{array}$ & Unknown & $\begin{array}{l}\text { Interaction with } \\
\text { Mla10 }\end{array}$ & TE-rich region & $\begin{array}{l}\text { Ridout et al., 2006; } \\
\text { Shen et al., } 2007\end{array}$ \\
\hline AvrK1 & 177 & Unknown & $\begin{array}{l}\text { Cytoplasm } \\
\text { (predicted) }\end{array}$ & Unknown & $\begin{array}{l}\text { Interaction with } \\
\text { Mlk1 }\end{array}$ & TE-rich region & Ridout et al., 2006 \\
\hline \multicolumn{8}{|c|}{ Cladosporium fulvum (biotroph; host: tomato) } \\
\hline Avr 2 & 78 & Unknown & Apoplast & In planta & $\begin{array}{l}\text { Interaction with } \\
\text { Cf2. Binds and } \\
\text { inhibits tomato } \\
\text { cysteine proteases } \\
\text { Rcr3 and Pip3 }\end{array}$ & Not reported & Dixon et al., 1996 \\
\hline Avr4 & 135 & Unknown & Apoplast & In planta & $\begin{array}{l}\text { Interaction with } \\
\text { Cf4. Protects } \\
\text { against chitinases }\end{array}$ & Not reported & $\begin{array}{l}\text { Joosten et al., } \\
\text { 1994; van den } \\
\text { Burg et al., } 2006\end{array}$ \\
\hline Avr4E & 121 & Unknown & Apoplast & In planta & $\begin{array}{l}\text { Interaction with } \\
\text { Cf4-E }\end{array}$ & Not reported & $\begin{array}{l}\text { Westerink et al., } \\
2004\end{array}$ \\
\hline Avr9 & 63 & Unknown & Apoplast & In planta & $\begin{array}{l}\text { Interaction with } \\
\text { Cf9 }\end{array}$ & Not reported & $\begin{array}{l}\text { van Kan et al., } \\
\text { 1991; van den } \\
\text { Hooven et al., } \\
2001\end{array}$ \\
\hline \multicolumn{8}{|c|}{ Extracellular proteins (Ecp) } \\
\hline Ecp1 & 65 & Unknown & Apoplast & In planta & $\begin{array}{l}\text { Required for full } \\
\text { virulence }\end{array}$ & Unknown & Lauge et al., 1997 \\
\hline \multirow[t]{2}{*}{ Ecp2 } & 143 & Unknown & Apoplast & In planta & $\begin{array}{l}\text { Required for full } \\
\text { virulence }\end{array}$ & Unknown & Lauge et al., 1997 \\
\hline & & Unknown & Apoplast & In planta & Unknown & Unknown & Lauge et al., 2000 \\
\hline Ecp5 & 98 & Unknown & Apoplast & In planta & Unknown & Unknown & Lauge et al., 2000 \\
\hline Ecp6 & 199 & Unknown & Apoplast & In planta & $\begin{array}{l}\text { Reduces plant } \\
\text { defense response } \\
\text { by binding to chitin }\end{array}$ & Unknown & Bolton et al., 2008 \\
\hline Ecp7 & 100 & Unknown & Apoplast & In planta & Unknown & Unknown & Bolton et al., 2008 \\
\hline \multicolumn{8}{|c|}{ Fusarium oxysporum f. sp. lycopersici (hemibiotroph; host: tomato) } \\
\hline Avr1 (Six4) & 242 & Unknown & Xylem & $\begin{array}{l}\text { Induced during } \\
\text { infection }\end{array}$ & Interaction with |-1 & $\begin{array}{l}\text { B-chromosome } \\
\text { (TE-rich region) }\end{array}$ & $\begin{array}{l}\text { Houterman et al., } \\
2008\end{array}$ \\
\hline Avr2 (Six3) & 163 & RxLR motif-like & $\begin{array}{l}\text { Xylem } \\
\text { (translocated to } \\
\text { cytoplasm) }\end{array}$ & $\begin{array}{l}\text { Induced during } \\
\text { infection }\end{array}$ & Interaction with I-2 & $\begin{array}{l}\text { B-chromosome } \\
\text { (TE-rich region) }\end{array}$ & $\begin{array}{l}\text { Houterman et al., } \\
2009\end{array}$ \\
\hline Avr3 (Six1) & 284 & Unknown & Xylem & $\begin{array}{l}\text { Stimulated by } \\
\text { living cells }\end{array}$ & $\begin{array}{l}\text { Interaction with } \\
\text { I-3. } \\
\text { Aggressiveness } \\
\text { determinant. }\end{array}$ & $\begin{array}{l}\text { B-chromosome } \\
\text { (TE-rich region) }\end{array}$ & Rep et al., 2004 \\
\hline \multicolumn{8}{|c|}{ Secreted in xylem proteins (SIX) } \\
\hline Six 5 & 119 & Unknown & Xylem & $\begin{array}{l}\text { Likely induced } \\
\text { during infection }\end{array}$ & $\begin{array}{l}\text { Required for } \\
\text { virulence; pairs } \\
\text { with Avr2 for full } \\
\text { I-2 resistance }\end{array}$ & $\begin{array}{l}\text { Chromosome 14; } \\
\text { upstream Avr2; } \\
\text { shares promoter } \\
\text { region }\end{array}$ & Ma et al., 2015 \\
\hline Six6 & 199 & Unknown & Xylem & $\begin{array}{l}\text { Induced during } \\
\text { infection }\end{array}$ & $\begin{array}{l}\text { Suppresses I-2 } \\
\text { mediated cell } \\
\text { death }\end{array}$ & B-chromosome & $\begin{array}{l}\text { Gawehns et al., } \\
2014\end{array}$ \\
\hline
\end{tabular}


TABLE 1 | Continued

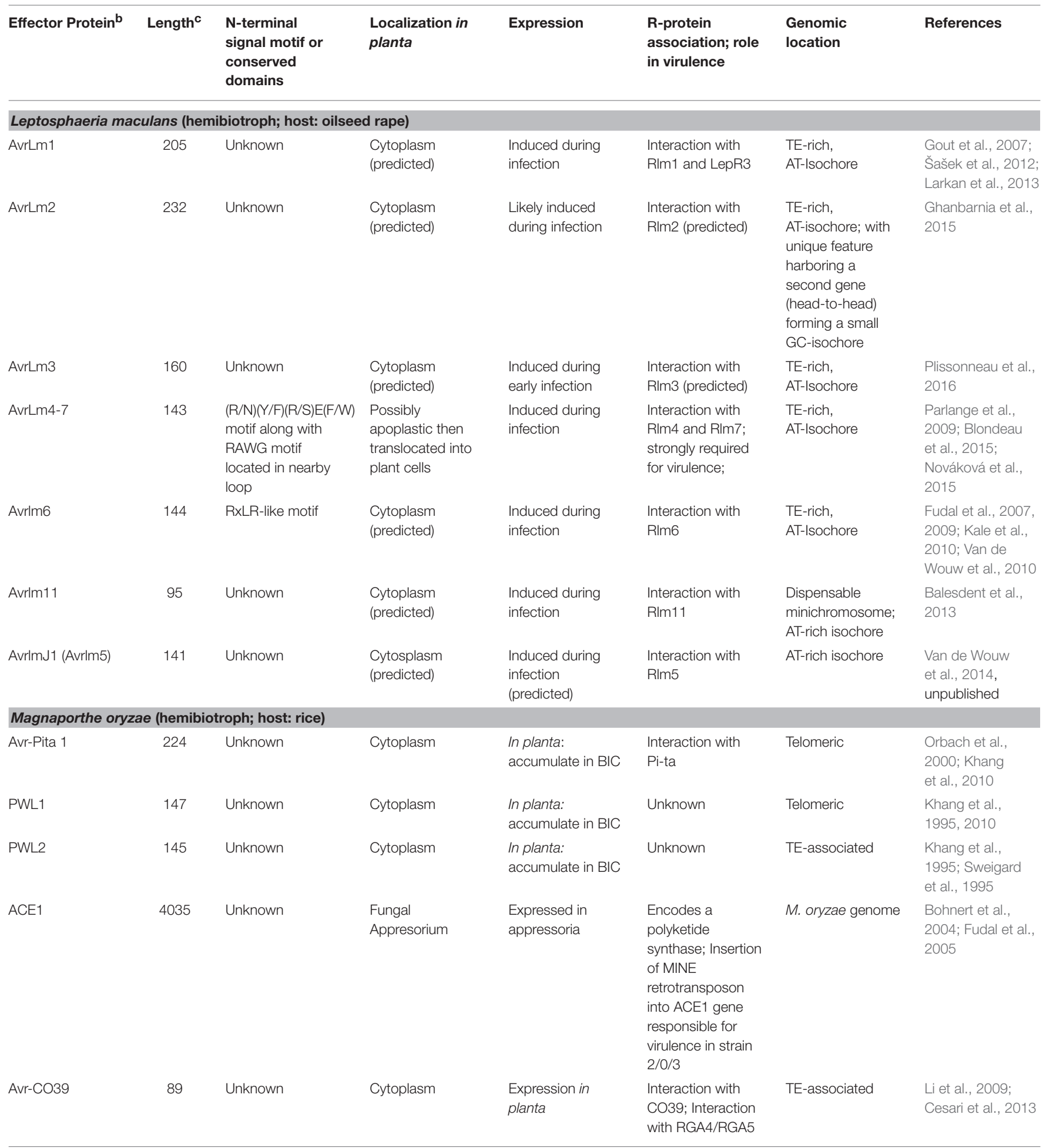


TABLE 1 | Continued

\begin{tabular}{|c|c|c|c|c|c|c|c|}
\hline Effector Protein ${ }^{b}$ & Length ${ }^{c}$ & $\begin{array}{l}\text { N-terminal } \\
\text { signal motif or } \\
\text { conserved } \\
\text { domains }\end{array}$ & $\begin{array}{l}\text { Localization in } \\
\text { planta }\end{array}$ & Expression & $\begin{array}{l}\text { R-protein } \\
\text { association; role } \\
\text { in virulence }\end{array}$ & $\begin{array}{l}\text { Genomic } \\
\text { location }\end{array}$ & References \\
\hline AvrPiz-t & 108 & Unknown & Unknown & Unknown & $\begin{array}{l}\text { Interaction with } \\
\text { Piz-t. Reduces } \\
\text { flg-22 and chitin } \\
\text { induced ROS } \\
\text { generation; } \\
\text { Targets U3 } \\
\text { ubiquitin ligase } \\
\text { from host for } \\
\text { degredation for } \\
\text { suppressing PTI }\end{array}$ & TE-associated & $\begin{array}{l}\text { Zhou et al., 2006; } \\
\text { Li et al., 2009; } \\
\text { Park et al., } 2012\end{array}$ \\
\hline AvrPia & 85 & Unknown & Cytoplasm & $\begin{array}{l}\text { Expression in } \\
\text { planta }\end{array}$ & $\begin{array}{l}\text { Interaction with } \\
\mathrm{Pi}-\mathrm{a}\end{array}$ & TE-associated & $\begin{array}{l}\text { Yoshida et al., } \\
2009\end{array}$ \\
\hline AvrPii & 70 & $\begin{array}{l}\mathrm{C} 2 \mathrm{H} 2 \text { zinc } \\
\text { finger-like motif }\end{array}$ & Cytoplasm & $\begin{array}{l}\text { Expression in } \\
\text { planta }\end{array}$ & Interaction with $\mathrm{Pi}-\mathrm{i}$ & $\begin{array}{l}\text { Subtelomeric and } \\
\text { TE-associated }\end{array}$ & $\begin{array}{l}\text { Yoshida et al., } \\
2009\end{array}$ \\
\hline AvrPik/km/kp & 113 & Unknown & Cytoplasm & $\begin{array}{l}\text { Expression in } \\
\text { planta }\end{array}$ & $\begin{array}{l}\text { Interaction with } \\
\mathrm{Pi}-\mathrm{k}\end{array}$ & Genome & $\begin{array}{l}\text { Yoshida et al., } \\
2009\end{array}$ \\
\hline AvrPib & 75 & Unknown & $\begin{array}{l}\text { Cytoplasm } \\
\text { (predicted) }\end{array}$ & Unknown & $\begin{array}{l}\text { Interaction with } \\
\text { Pi-b }\end{array}$ & TE-associated & Zhang et al., 2015 \\
\hline \multicolumn{8}{|c|}{ Secreted LysM protein } \\
\hline SLP1 & 162 & LysM domain & Apoplast & $\begin{array}{l}\text { Expression in } \\
\text { planta }\end{array}$ & $\begin{array}{l}\text { Required for full } \\
\text { virulence; Binds } \\
\text { chitin and } \\
\text { suppresses } \\
\text { chitin-induced } \\
\text { plant immune } \\
\text { response }\end{array}$ & Not reported & $\begin{array}{l}\text { Mentlak et al., } \\
2012\end{array}$ \\
\hline MC69 & 54 & $\begin{array}{l}\text { No signal motifs } \\
\text { identified }\end{array}$ & Apoplastic & $\begin{array}{l}\text { Expression during } \\
\text { early infection } \\
\text { stage }\end{array}$ & $\begin{array}{l}\text { Required for } \\
\text { virulence }\end{array}$ & Chromosome 6 & Saitoh et al., 2012 \\
\hline \multicolumn{8}{|c|}{ Biotrophy-associated secreted (BAS) proteins } \\
\hline BAS1 & 115 & Unknown & Cytoplasm & $\begin{array}{l}\text { In planta: } \\
\text { accumulate in } \mathrm{BIC}\end{array}$ & Unknown & Unknown & $\begin{array}{l}\text { Mosquera et al., } \\
2009\end{array}$ \\
\hline BAS2 & 102 & Unknown & $\begin{array}{l}\text { Cell wall crossing } \\
\text { points }\end{array}$ & $\begin{array}{l}\text { In planta: } \\
\text { accumulate in } \mathrm{BIC}\end{array}$ & Unknown & Unknown & $\begin{array}{l}\text { Mosquera et al., } \\
2009\end{array}$ \\
\hline BAS3 & 113 & Unknown & $\begin{array}{l}\text { Cell wall crossing } \\
\text { points }\end{array}$ & $\begin{array}{l}\text { In planta: } \\
\text { accumulate in } \mathrm{BIC}\end{array}$ & Unknown & Unknown & $\begin{array}{l}\text { Mosquera et al., } \\
2009\end{array}$ \\
\hline BAS4 & 102 & Unknown & $\mathrm{BIC}$ & In planta & Unknown & Unknown & $\begin{array}{l}\text { Mosquera et al., } \\
2009\end{array}$ \\
\hline \multicolumn{8}{|c|}{ Melamspora lini (biotroph; host: flax) } \\
\hline AvrL567 & 150 & RxLR-like motif & Cytoplasm & $\begin{array}{l}\text { Expressed in } \\
\text { haustoria }\end{array}$ & $\begin{array}{l}\text { Interaction with } \\
\text { L5, L6, and L7 Not } \\
\text { required for full } \\
\text { virulence }\end{array}$ & Unknown & $\begin{array}{l}\text { Dodds et al., } \\
\text { 2004; Lawrence } \\
\text { et al., } 2010\end{array}$ \\
\hline AvrM & 314 & RxLR-like motif & Cytoplasm & $\begin{array}{l}\text { Expressed in } \\
\text { haustoria }\end{array}$ & Interaction with $\mathrm{M}$ & Unknown & $\begin{array}{l}\text { Catanzariti et al., } \\
2006 \text {; Kale et al., } \\
2010\end{array}$ \\
\hline AvrP123 & 117 & Unknown & Cytoplasm & $\begin{array}{l}\text { Expressed in } \\
\text { haustoria }\end{array}$ & $\begin{array}{l}\text { Interaction with } \\
\text { P1, P2 and P3 }\end{array}$ & Unknown & $\begin{array}{l}\text { Catanzariti et al., } \\
2006\end{array}$ \\
\hline AvrP4 & 95 & Unknown & Cytoplasm & $\begin{array}{l}\text { Expressed in } \\
\text { haustoria }\end{array}$ & Interaction with P4 & Unknown & $\begin{array}{l}\text { Catanzariti et al., } \\
2006\end{array}$ \\
\hline \multicolumn{8}{|c|}{ Puccinia graminis f. sp tritci (biotroph; hosts: wheat and barley) } \\
\hline RGDBP & 818 & RGD motif & Apoplast & Constitutive & $\begin{array}{l}\text { Interaction with } \\
\text { Rpg1 }\end{array}$ & Unknown & $\begin{array}{l}\text { Nirmala et al., } \\
2011\end{array}$ \\
\hline VPS9 & 744 & $\begin{array}{l}\text { Forms complex } \\
\text { with RGDBP }\end{array}$ & Apoplast & Constitutive & $\begin{array}{l}\text { Interaction with } \\
\text { RpgA }\end{array}$ & Unknown & $\begin{array}{l}\text { Nirmala et al., } \\
2011\end{array}$ \\
\hline
\end{tabular}


TABLE 1 | Continued

\begin{tabular}{|c|c|c|c|c|c|c|c|}
\hline Effector Protein ${ }^{b}$ & Length ${ }^{c}$ & $\begin{array}{l}\mathrm{N} \text {-terminal } \\
\text { signal motif or } \\
\text { conserved } \\
\text { domains }\end{array}$ & $\begin{array}{l}\text { Localization in } \\
\text { planta }\end{array}$ & Expression & $\begin{array}{l}\text { R-protein } \\
\text { association; role } \\
\text { in virulence }\end{array}$ & $\begin{array}{l}\text { Genomic } \\
\text { location }\end{array}$ & References \\
\hline PGTAUSPE-10-1 & Unknown & Unknown & Unknown & $\begin{array}{l}\text { Expressed in } \\
\text { haustoria }\end{array}$ & $\begin{array}{l}\text { Possible } \\
\text { interaction with } \\
\text { Sr22 }\end{array}$ & Unknown & $\begin{array}{l}\text { Upadhyaya et al., } \\
2014\end{array}$ \\
\hline \multicolumn{8}{|c|}{ Ustilago maydis (biotroph; host: maize) } \\
\hline $\begin{array}{l}\text { Pep1 (protein } \\
\text { essential for } \\
\text { penetration1) }\end{array}$ & 178 & Not reported & Apoplast & $\begin{array}{l}\text { Induced during } \\
\text { early infection }\end{array}$ & $\begin{array}{l}\text { Required for full } \\
\text { virulence; Directly } \\
\text { interacts with } \\
\text { POX12 and } \\
\text { suppresses plant } \\
\text { defense by } \\
\text { scavenging ROS }\end{array}$ & Not reported & $\begin{array}{l}\text { Doehlemann et al., } \\
\text { 2009; } \\
\text { Hemetsberger } \\
\text { et al., 2012; Hof } \\
\text { et al., 2014 }\end{array}$ \\
\hline Cmu1 & & Not reported & Apoplast & $\begin{array}{l}\text { Induced during } \\
\text { infection }\end{array}$ & $\begin{array}{l}\text { Required for full } \\
\text { virulence; A } \\
\text { chorismate } \\
\text { mutase that } \\
\text { potentially } \\
\text { cooperates with } \\
\text { maize chorismate } \\
\text { mutase to reduce } \\
\text { available SA }\end{array}$ & Not reported & $\begin{array}{l}\text { Eberhard et al., } \\
\text { 1996; Djamei } \\
\text { et al., } 2011\end{array}$ \\
\hline \multicolumn{8}{|c|}{ Phytophthora infestans (oomocyte; hosts: potato and tomato) } \\
\hline Avr2 & 118 & RxLR motif & Cytoplasm & $\begin{array}{l}\text { Induced during } \\
\text { infection }\end{array}$ & Interaction with R2 & TE-rich & $\begin{array}{l}\text { Lokossou et al., } \\
\text { 2009; Gilroy et al., } \\
\text { 2011b }\end{array}$ \\
\hline Avr3a & 147 & RxLR motif & Cytoplasm & $\begin{array}{l}\text { Induced during } \\
\text { infection }\end{array}$ & $\begin{array}{l}\text { Interaction with } \\
\text { R3a; } \\
\text { INF1-meidated } \\
\text { plant death }\end{array}$ & TE-rich & $\begin{array}{l}\text { Armstrong et al., } \\
\text { 2005; Bos et al., } \\
\text { 2010; Gilroy et al., } \\
\text { 2011a }\end{array}$ \\
\hline Avr4 & 287 & RxLR motif & Likely cytoplasm & $\begin{array}{l}\text { Induced during } \\
\text { infection }\end{array}$ & Interaction with R4 & TE-rich & $\begin{array}{l}\text { van Poppel et al., } \\
2008,2009\end{array}$ \\
\hline AvrBlb1; Ipi01 & 153 & RxLR motif & Cytoplasm & $\begin{array}{l}\text { Induced during } \\
\text { infection }\end{array}$ & $\begin{array}{l}\text { Interaction with } \\
\text { RpiBlb1; Disrupts } \\
\text { cell wall-plasma } \\
\text { membrane } \\
\text { adhesion }\end{array}$ & TE-rich & $\begin{array}{l}\text { Pieterse et al., } \\
\text { 1994; Senchou } \\
\text { et al., 2004; } \\
\text { Vleeshouwers } \\
\text { et al., } 2008\end{array}$ \\
\hline AvrBlb2 & 101 & RxLR motif & Cytoplasm & $\begin{array}{l}\text { Induced during } \\
\text { infection }\end{array}$ & $\begin{array}{l}\text { Interaction with } \\
\text { RpiBlb2; Required } \\
\text { for full virulence; } \\
\text { blocks plant } \\
\text { protease secretion }\end{array}$ & TE-rich & $\begin{array}{l}\text { Oh et al., 2009; } \\
\text { Bozkurt et al., } \\
2011\end{array}$ \\
\hline
\end{tabular}


TABLE 1 | Continued

\begin{tabular}{|c|c|c|c|c|c|c|c|}
\hline Effector Protein ${ }^{b}$ & Length ${ }^{c}$ & $\begin{array}{l}\mathrm{N} \text {-terminal } \\
\text { signal motif or } \\
\text { conserved } \\
\text { domains }\end{array}$ & $\begin{array}{l}\text { Localization in } \\
\text { planta }\end{array}$ & Expression & $\begin{array}{l}\text { R-protein } \\
\text { association; role } \\
\text { in virulence }\end{array}$ & $\begin{array}{l}\text { Genomic } \\
\text { location }\end{array}$ & References \\
\hline $\begin{array}{l}\text { SNE1 (Suppressor } \\
\text { of Necrosis } 1 \text { ) }\end{array}$ & 291 & RxLR motif & Cytoplasm & $\begin{array}{l}\text { Induced during } \\
\text { infection }\end{array}$ & $\begin{array}{l}\text { Suppresses } \\
\text { NLP-triggered and } \\
\text { effector-triggered } \\
\text { cell death }\end{array}$ & TE-rich & Kelley et al., 2010 \\
\hline PiCRN2 & 456 & $\begin{array}{l}\text { Conserved FLAK } \\
\text { (for Phe, Leu, Ala, } \\
\text { Lys) motif }\end{array}$ & Cytoplasm & $\begin{array}{l}\text { Induced during } \\
\text { infection }\end{array}$ & $\begin{array}{l}\text { Triggers plant cell } \\
\text { death }\end{array}$ & TE-rich & $\begin{array}{l}\text { Schornack et al., } \\
2010\end{array}$ \\
\hline PiCRN8 & 599 & $\begin{array}{l}\text { Conserved FLAK } \\
\text { motif }\end{array}$ & Cytoplasm & $\begin{array}{l}\text { Induced during } \\
\text { infection }\end{array}$ & $\begin{array}{l}\text { Triggers plant cell } \\
\text { death; C-terminal } \\
\text { kinase-like domain } \\
\text { exhibits kinase } \\
\text { activity-suggests } \\
\text { role in modification } \\
\text { of host-cell } \\
\text { signaling pathway }\end{array}$ & TE-rich & $\begin{array}{l}\text { Schornack et al., } \\
\text { 2010; Liu et al., } \\
2011\end{array}$ \\
\hline PiCRN15 & 615 & $\begin{array}{l}\text { Conserved FLAK } \\
\text { motif }\end{array}$ & Cytoplasm & $\begin{array}{l}\text { Induced during } \\
\text { infection }\end{array}$ & $\begin{array}{l}\text { Triggers plant cell } \\
\text { death }\end{array}$ & TE-rich & $\begin{array}{l}\text { Schornack et al., } \\
2010\end{array}$ \\
\hline PiCRN16 & 618 & $\begin{array}{l}\text { Conserved FLAK } \\
\text { motif }\end{array}$ & Cytoplasm & $\begin{array}{l}\text { Induced during } \\
\text { infection }\end{array}$ & $\begin{array}{l}\text { Triggers plant cell } \\
\text { death }\end{array}$ & TE-rich & $\begin{array}{l}\text { Schornack et al., } \\
2010\end{array}$ \\
\hline \multicolumn{8}{|c|}{ Extracellular protease inhibitors (EPI) } \\
\hline EPIC1 & 126 & $\begin{array}{l}\text { Cystatin-like } \\
\text { domain }\end{array}$ & Apoplast & $\begin{array}{l}\text { Induced during } \\
\text { infection }\end{array}$ & $\begin{array}{l}\text { Binds and inhibits } \\
\text { tomato cysteine } \\
\text { proteases Rcr3 } \\
\text { and PIP1 }\end{array}$ & Not reported & $\begin{array}{l}\text { Tian et al., 2007; } \\
\text { Song et al., } 2009\end{array}$ \\
\hline EPIC2A & 125 & $\begin{array}{l}\text { Cystatin-like } \\
\text { domain }\end{array}$ & Apoplast & Unknown & Unknown & Not reported & Tian et al., 2007 \\
\hline EPI1 & 149 & $\begin{array}{l}\text { Cystatin-like } \\
\text { domain }\end{array}$ & Apoplast & $\begin{array}{l}\text { Induced during } \\
\text { infection }\end{array}$ & $\begin{array}{l}\text { Binds and inhibits } \\
\text { tomato serine } \\
\text { protease P69B }\end{array}$ & Not reported & Tian et al., 2004 \\
\hline EPI10 & 228 & $\begin{array}{l}\text { Cystatin-like } \\
\text { domain }\end{array}$ & Apoplast & $\begin{array}{l}\text { Induced during } \\
\text { infection }\end{array}$ & $\begin{array}{l}\text { Binds and inhibits } \\
\text { tomato serine } \\
\text { protease P69B }\end{array}$ & Not reported & Tian et al., 2005 \\
\hline \multicolumn{8}{|c|}{ Phytophthora sojae (oomocyete; host: soybean) } \\
\hline Avr1b-1 & 138 & RxLR motif & Cytoplasm & $\begin{array}{l}\text { Induced during } \\
\text { infection }\end{array}$ & $\begin{array}{l}\text { Interaction with } \\
\text { Rps } 1 \mathrm{~b} \text { and Rps } 1 \mathrm{k} \text {; } \\
\text { Suppresses plant } \\
\text { cell death }\end{array}$ & TE-rich & $\begin{array}{l}\text { Shan et al., 2004; } \\
\text { Dou et al., 2008b }\end{array}$ \\
\hline Avr1a & 122 & RxLR motif & Cytoplasm & In planta & $\begin{array}{l}\text { Interaction with } \\
\text { Rps1a }\end{array}$ & TE-rich & Qutob et al., 2009 \\
\hline Avh331; Avr1k & 279 & RxLR motif & Cytoplasm & $\begin{array}{l}\text { Induced during } \\
\text { infection }\end{array}$ & $\begin{array}{l}\text { Interaction with } \\
\text { Rpsk; Strongly } \\
\text { suppresses } \\
\text { PAMP-triggered } \\
\text { and } \\
\text { effector-triggered } \\
\text { cell death }\end{array}$ & TE-rich & $\begin{array}{l}\text { Dou et al., 2008b; } \\
\text { Kale et al., } 2010\end{array}$ \\
\hline
\end{tabular}


TABLE 1 | Continued

\begin{tabular}{|c|c|c|c|c|c|c|c|}
\hline Effector Protein ${ }^{b}$ & Length $\mathrm{c}$ & $\begin{array}{l}\text { N-terminal } \\
\text { signal motif or } \\
\text { conserved } \\
\text { domains }\end{array}$ & $\begin{array}{l}\text { Localization in } \\
\text { planta }\end{array}$ & Expression & $\begin{array}{l}\text { R-protein } \\
\text { association; role } \\
\text { in virulence }\end{array}$ & $\begin{array}{l}\text { Genomic } \\
\text { location }\end{array}$ & References \\
\hline Avr3a/5 & $111-119$ & RxLR motif & Cytoplasm & $\begin{array}{l}\text { Induced during } \\
\text { infection }\end{array}$ & $\begin{array}{l}\text { Interaction with } \\
\text { Rps3a and Rps5; } \\
\text { Suprresses } \\
\text { effector-triggered } \\
\text { cell death }\end{array}$ & TE-rich & $\begin{array}{l}\text { Qutob et al., 2009; } \\
\text { Dong et al., 2011; } \\
\text { Wang et al., } 2011\end{array}$ \\
\hline Avr3b & 314 & RxLR motif & Cytoplasm & $\begin{array}{l}\text { Strongly induced } \\
\text { in germinating } \\
\text { cysts and during } \\
\text { infection }\end{array}$ & $\begin{array}{l}\text { Interaction with } \\
\text { Rps3b; } \\
\text { Suppresses } \\
\text { effector-triggered } \\
\text { cell death and } \\
\text { ROS production }\end{array}$ & TE-rich & Dong et al., 2011 \\
\hline Avr3c & 220 & RxLR motif & Cytoplasm & $\begin{array}{l}\text { Expressed in early } \\
\text { infection stage }\end{array}$ & $\begin{array}{l}\text { Interaction with } \\
\text { Rps3c }\end{array}$ & TE-rich & Dong et al., 2009 \\
\hline Avr4/6 & 123 & RxLR motif & Cytoplasm & $\begin{array}{l}\text { Induced during } \\
\text { infection }\end{array}$ & $\begin{array}{l}\text { Interaction with } \\
\text { Rps4 and Rps6 }\end{array}$ & TE-rich & Dou et al., 2010 \\
\hline Avr1d & 125 & RxLR motif & Cytoplasm & $\begin{array}{l}\text { Induced during } \\
\text { infection }\end{array}$ & $\begin{array}{l}\text { Interaction with } \\
\text { Rps1d; } \\
\text { Suppressed BAX } \\
\text { (proapoptotic } \\
\text { protein)-induced } \\
\text { cell death }\end{array}$ & TE-rich & $\begin{array}{l}\text { Na et al., 2013; } \\
\text { Yin et al., } 2013\end{array}$ \\
\hline Avh172 & 218-227 & RxLR motif & Cytoplasm & $\begin{array}{l}\text { Expressed in early } \\
\text { infection stage }\end{array}$ & $\begin{array}{l}\text { Suppresses } \\
\text { effector-triggered } \\
\text { cell death; } \\
\text { Required for } \\
\text { virulence }\end{array}$ & TE-rich & Wang et al., 2011 \\
\hline Avh238 & $134-142$ & RxLR motif & Cytoplasm & $\begin{array}{l}\text { Induced during } \\
\text { infection }\end{array}$ & $\begin{array}{l}\text { Suppresses } \\
\text { PAMP-triggered } \\
\text { cell death; required } \\
\text { for full virulence }\end{array}$ & TE-rich & Wang et al., 2011 \\
\hline PsCRN63 & 450 & $\begin{array}{l}\text { Conserved FLAK } \\
\text { motif }\end{array}$ & Cytoplasm & $\begin{array}{l}\text { Constitutive; } \\
\text { Slightly induced } \\
\text { during infection }\end{array}$ & $\begin{array}{l}\text { Triggers plant cell } \\
\text { death }\end{array}$ & TE-rich & Liu et al., 2011 \\
\hline PsCRN115 & 449 & $\begin{array}{l}\text { Conserved FLAK } \\
\text { motif }\end{array}$ & Cytoplasm & $\begin{array}{l}\text { Constitutive; } \\
\text { Slightly induced } \\
\text { during infection }\end{array}$ & $\begin{array}{l}\text { Suppresses plant } \\
\text { cell death }\end{array}$ & TE-rich & Liu et al., 2011 \\
\hline PsNPP1; NLPps & 237 & Not reported & Apoplast & $\begin{array}{l}\text { Induced during } \\
\text { transition to } \\
\text { necrotrophy }\end{array}$ & $\begin{array}{l}\text { Triggers plant cell } \\
\text { death }\end{array}$ & TE-rich & Qutob et al., 2006 \\
\hline
\end{tabular}

a Plant pathogenic fungi listed in table are known to infect crop plants (excluded Arabidopsis thaliana).

${ }^{b}$ Includes proteins that have shown specific host-interaction phenotypes or indication of host cell entry.

${ }^{c}$ The number of amino acid residues within the unprocessed protein.

Koeck et al., 2011; Petre and Kamoun, 2014). Obligate biotrophs such as rust fungi or powdery mildew fungi are only capable of propagating on living host tissue. After penetration of the epidermal cell wall, a lobed haustorium develops within the meshophyll (Manners and Gay, 1983; Mackie et al., 1991; Harrison, 1998). The haustorium is completely surrounded by a membrane termed the extrahaustorial membrane, which appears to be an invagination of the plant plasma membrane (Garnica et al., 2014). Interestingly, the biotroph Ustilago maydis does not establish bulbous feeding structures similar to the haustoria-forming rust fungi. During penetration, the host plasma membrane invaginates and completely encloses the intracellular hyphae, establishing an extensive area of interaction where the exchange of molecules between the fungus and host occurs (Djamei and Kahmann, 2012; Lo Presti et al., 2015). Hemibiotrophic pathogens utilize a biotrophic phase early in the infection process followed by a necrotrophic phase killing host cells to complete their lifecycle. For the hemibiotrophic pathogen, Magnaporthe oryzae, two discrete secretion systems for delivery of apoplastic and cytoplasmic effectors are utilized (Giraldo et al., 2013). For cytoplasmic effector delivery, these proteins appear to accumulate in the biotrophic interface complex (BIC) near the tip of the first bulbous cell formed after host cell penetration. Apoplastic effectors, on the other hand, are not associated with 
BIC, and once secreted they are dispersed in the extracellular space between the fungal cell wall and the extra-invasive-hyphal membrane (Giraldo et al., 2013; Zhang and Xu, 2014). There have been no studies to elucidate effector delivery strategies employed by the pathogen Leptosphaeria maculans, a hemibiotroph that causes disease in Brassica plant species. However, one might speculate that it uses a mechanism similar to that of M. oryzae, where some of the cytoplasmic Avr effectors accumulate at the BIC. One particular review suggested that L. maculans was an apoplastic pathogen and unlike BIC-forming hemibiotrophs, it triggers a slower defense response where maximum expression of the effectors does not occur until after an initial endophytic growth phase (Stotz et al., 2014).

\section{TARGETING OF EFFECTORS TO HOST CELLS}

No system analogous to the bacterial secretion system has been identified in fungi. However, one common theme that has emerged in terms of fungal effector secretion is based on host targeting via $\mathrm{N}$-terminal translocation domains, which are found after the general secretory signal peptide. Insights into the effector movement process have come from studies conducted with oomycete pathogens, which employ a similar infection strategy that are used by fungi (Koeck et al., 2011). In the oomycetes, secreted effector proteins share a common N-terminal host targeting domain, which contains common motifs such as RxLR (Arg-x-Leu-Arg), LxLFLAK or CRN (Crinkler motif) and $\mathrm{CHxC}$ amino acid sequences (Jiang et al., 2008). The N-terminal RxLR motif along with a downstream DEER (Asp-Glu-Glu-Arg) amino acid sequence in the Avr3a effector protein of Phytopthera infestans has been shown to be required for translocation into potato cells (Whisson et al., 2007; Dou et al., 2008a; Bos et al., 2010; Kale et al., 2010).

Identification of $\mathrm{N}$-terminal signal motifs involved in cell entry is not as clearly defined for most fungi as it appears to be for oomycetes. In general, fungal effectors do not appear to share significant sequence similarity; a feature attributed to its rapid variation and host adaptation (Sperschneider et al., 2015a), although some exceptions have been reported. For example, the Cladosporium fulvum Ecp6 effector contains a LysM domain, which was shown to align with 16 putative C. fulvum Ecp6-like proteins from: Aspergillus niger, Magnaporthe grisea, Mycosphaerella fijiensis, M. graminicola, Botrytis cinerea, Sclerotinia sclerotiorum, A. nidulans, A. oryzae, A flavus, C. lindemuthianum, and L. maculans (Bolton et al., 2008). Also, a chorismate mutase effector, Cmu1, secreted by the maize pathogen $U$. maydis, illustrated a role in virulence, suggesting that some effectors may, based on protein sequence, have predicted functional roles (Djamei et al., 2011). It should be noted that evidence exists demonstrating conservation within the $\mathrm{N}$-terminal sequence motifs of some fungi. In the barley powdery mildew fungus, Blumeria gramanis $\mathrm{f}$. sp. hordei, for example, the effector proteins share an $\mathrm{N}$-terminal [YFW] $\mathrm{xC}$ motif within 30 amino acids of the signal peptide (Godfrey et al., 2010). This particular motif has also been reported in other effectors found within rust fungi, but amino acid position within the proteins is less conserved (Duplessis et al., 2011). In the genus Fusarium, a set of effector proteins share a conserved [SG]PC[KR]P motif located immediately downstream of the Nterminal signal peptide. However, these motifs have yet to be functionally characterized and remain undetermined whether they are indeed fungal effector motifs (Manning et al., 2008). In Melamspora lini, the AvrL567 and AvrM effectors enter flax cells autonomously which is governed by N-terminal uptake domains, but the two proteins do not share conserved motifs or structures (Rafiqi et al., 2010).

Other features that may unite groups of effectors include structural similarities, for example the arrangement of secondary structural elements relative to each other, i.e., three-dimensional folds. Studies with the genus Phytophthora proteins AVR3a11 and PexRD2 suggested a three-helix bundle fold as the basic structural unit, which is formed by the repeating WY motifs. This particular structural element has been identified in more than 520 related RxLR effector proteins (Boutemy et al., 2011). Interestingly, a duplicated four helical motif with similarity to the WY domain of oomycete effectors was illustrated in the M. lini AvrM effector. In a recent study by Goritschnig et al. (2016), the WY-domain of an effector produced by Hyloperonospora Arabidopsis (ATR1) was shown to be directly recognized by the Arabidopsis NLR RPP1 through association with the C-terminal LRR (Goritschnig et al., 2016), suggesting that this feature may be important for NLR recognition. Other features such as $\beta$-sandwich structures have also been discovered in AvrL567 from M. lini (Wang et al., 2007) and in the M. oryzae effector Piz-t (Zhang et al., 2013), suggesting that structural conservation exists among some fungal effectors. Despite this commonality, a lack of significant effector protein conservation is expected to hamper the use of these features for predicting effector function.

\section{IDENTIFYING AND PREDICTING EFFECTOR CANDIDATES}

Prior to the advent of genomic sequencing, identification of many effectors was carried out by genetic map-based cloning. Examples include AvrPi-ta (Orbach et al., 2000), ACE1 (Bohnert et al., 2004), and Avr-CO39 (Farman and Leong, 1998) from M. oryzae; AvrLm1 (Gout et al., 2006), Avrlm4-7 (Parlange et al., 2009), AvrLm6 (Fudal et al., 2007) from L. maculans. The availability of transcriptomic and fungal genomic sequences has accelerated the number of effectors identified in the last decade. By screening for cDNA clones that associate with avirulence loci, Avr3a (Armstrong et al., 2005) and Avr4 (van Poppel et al., 2009) from P. infestans and AvrL567 from M. lini (Dodds et al., 2004) were identified and characterized. In some cases expressed sequence tags (EST) were screened bioinformatically to identify potential secreted proteins with specific N-terminal secretion signals (Vleeshouwers et al., 2008; Oh et al., 2009; Zhu et al., 2012). Interestingly, analysis of a cDNA library from barley tissue containing the ascomycete $B$. graminis $\mathrm{f}$. sp. hordei illustrated that the majority of expressed fungal genes encoded unrelated small proteins containing $\mathrm{N}$-terminal 
signal peptides and an N-terminal motif of [YFW] xC (Godfrey et al., 2010). Identification of effectors using these types of approaches defined structural properties of effector proteins allowing for bioinformatic predictions of putative effectors. Prediction of hundreds of potential RxLR effector genes in P. sojae, P. ramorum, P. infestans (Tyler et al., 2006; Jiang et al., 2008; Haas et al., 2009), L. maculans (Rouxel et al., 2011) and powdery mildew fungi were made possible through using a bioinformatic strategy.

Despite the identification of conserved sequence features among effectors, fungal effector prediction approaches remain problematic as they are largely based on relatively broad criteria, which principally rely on the presence of a secretion signal and the fact that the majority of effector proteins are small in size and cysteine-rich (Sperschneider et al., 2015a). These features have been used to mine predicted secretomes, and although it is helpful in reducing the number of candidates, the problem remains that not all secreted small cysteine rich proteins will function as an effector and conversely not all fungal effectors will be small and cysteine-rich. For instance, some cytoplasmic effectors translocated into the host cell are low in cysteine residues and are quite large in size. In L. maculans, AvrLm1 effector has only one cysteine residue (Gout et al., 2006), suggesting that the criteria of small and cysteine rich, while being valuable for apoplastic effectors, may have a tendency to exclude potential effector candidates (Sperschneider et al., 2015b).

New approaches for predicting both apoplastic and cytoplasmic effector candidates have been developed that do not rely solely on the presence of a secretion signal, small size and high cysteine residue content. Saunders et al. (2012) designed a thorough in silico analysis to identify the potential effector repertoire from the genome of two pathogenic rust fungi. The pipeline is founded on the observation that known effector proteins from filamentous pathogens have at least one of the following properties: (i) the presence of a secretion signal, (ii) being encoded by genes that are induced in planta, (iii) exhibiting similarity to haustorial proteins, (iv) small and cysteine rich, (v) the presence of a known effector motif or a nuclear localization signal, (vi) being encoded by genes with long intergenic regions, (vii) the presence of internal repeats, (viii) a lack of PFAM domains, excluding those associated with pathogenicity. The authors then used clustering algorithms to group protein families of rust pathogens and rank them according to the likelihood of being effectors. Using this approach they were able to identify approximately eight families of effector contenders. This pipeline was also utilized in a study conducted on M. lini, where 200 potential effector candidates were identified (Nemri et al., 2014), suggesting that this methodology may be useful in future effector predictions. A similar strategy was developed to predict effector candidates in S. sclerotiorum. This method involved the equivalent selection pipeline utilized by Saunders et al. (2012), as described above, in addition to selection of proteins belonging to duplicated gene families, and those that illustrated signatures of positive selection (Guyon et al., 2014). With this strategy, the authors were able to putatively identify 78 effector candidates from a predicted proteome of over 14,500 proteins (Guyon et al., 2014), suggesting that the additional criterion for selection within this pipeline could potentially narrow down the number of effector candidates, although more studies need to be carried out to ensure that potential effector proteins are not being missed. Taken together, these studies clearly illustrate that with the development of computational algorithms and enhancement of specific analytical criteria for protein selection pipelines, predicting fungal effectors is becoming more efficient. By looking beyond sequence similarity based methods and integrating relevant physiological effector functions such as gene expression in planta, genomic features, or taxonomic information, computational analytical algorithms will prove to be an extremely powerful tool for predicting effector candidates within a large proteome.

Proteomics is another important tool utilized for largescale studies on proteins that are involved in plant-pathogen interactions. Characterization of a subset of proteins during plant-pathogen interactions has been able to provide a more direct view of cellular processes compared to DNA or RNA analysis and has resulted in the identification of both fungal and oomocyte effectors (Ricci et al., 1989; Kamoun et al., 1993; De Wit et al., 2002; Rose et al., 2002; Rep et al., 2004; Xu et al., 2007; Houterman et al., 2008, 2009; Cao et al., 2009). One of the first studies using proteomics to identify an avirulence gene was carried out by De Wit research group (1986 and 1988) on the pathogenic fungi C. fulvum. In these studies, the gene product encoded by avr9 (Avr9) was characterized through protein purification of tomato apoplastic fluids during compatible/incompatible fungal-plant host interactions using polyacrylamide gel electrophoresis (PAGE), reverse-phase HPLC and EDMAN N-terminal sequencing (De Wit et al., 1986; Schottens-Toma and DeWit, 1988). In F. oxysporum f. sp lycopersici (FOL), one of the first effectors, termed SIX1 (Avr3), was identified and sequenced using mass spectrometry (MS) (Rep et al., 2004). More specifically, the peptide sequence SIX1 was obtained from purification of xylem sap from infected tomato plants, and a gene deletion was able to further confirm that the absence of the SIX1 gene resulted in the loss of resistance on an I-3 (corresponding R gene) tomato line. Other studies conducted in the FOL isolate followed suite, where identification of 14 additional SIX proteins were determined through the analysis of the xylem sap proteome of infected tomato plants using two-dimensional gel separation and mass spectrometry (Houterman et al., 2008, 2009; Lievens et al., 2009; Ma et al., 2010; Schmidt et al., 2013). A recent study using a large-scale proteomics approach determined the protein changes in the xylem sap proteome following FOL infection from analyzing plants inoculated with either the wild type or SIX knockout FOL isolates (Gawehns et al., 2015). The authors illustrated that the absence of a single effector altered the abundance of the sap xylem proteins, which corresponded to the altered virulence visualized on the plants inoculated with the SIX knockout strains (Gawehns et al., 2015). Clearly, proteomics is an extremely effective tool for finding effector proteins that are expressed during pathogen-host interactions. Even though there are some limitations associated with this type of technique, such as low protein abundance, sample complexity, sensitivity, resolution, and speed of data acquisition (Gonzalez-Fernandez et al., 2010), 
proteomics appears to be more direct, where proteins that are necessary for plant-pathogen interactions are more precisely identified. This is in contrast to computational prediction systems, which have a tendency to broadly select effector proteins that may or may not have an actual function in plant-pathogen interactions. Furthermore, a more global application can be used in proteomics where the overall contribution of a specific effector on the abundance of proteins within the proteome can be assessed. This type of global analysis will allow for a better understanding of plant-pathogen association and provide insight into the mechanism involved in effector recognition.

\section{FACTORS THAT AFFECT EVOLUTIONARY CHANGES IN EFFECTORS}

With the development of new computational tools for predicting effectors, researchers have focused their attention on how factors such as genome structure and gene transfer impact fungal effector composition. Fungal effector composition seems to be driven by the evolutionary arms race between effector recognition by plant R-proteins, however where they are located within the genome and how they are transferred from one isolate to another can significantly influence fungal effector repertoire.

Association of the pathogen with its host plant results in either an incompatible (resistant) or a compatible (susceptible) interaction. The fundamental principle explaining the outcome of this interaction is based on the gene-for-gene model (Flor, 1956). This model proposes that the product of the R-gene from the host plant distinguishes an Avr (Avirulent) effector produced by the pathogen leading to a resistant or incompatible reaction. If there is no detection, as a result of allelic variation or lack of one of two components, then a susceptible or compatible reaction is observed. Interestingly, plant-associated microbes continually evolve new effectors to retain or improve their ability to cause disease and to minimize detection by a plant host. Plants are also compelled to maintain disease resistance and improve their ability to detect pathogen effectors by developing new R-gene allelic varations. The antagonistic cycles of evolution between pathogen effectors and plant R-proteins is described as the co-evolutionary "arms-race" or zigzag model (Jones and Dangl, 2006; Dodds and Rathjen, 2010; Tyler and Rouxel, 2013). As a result of this arms race, the genotype for each of these proteins become highly polymorphic and include singlenucleotide polymorphisms (SNPs), insertions and deletions within the gene sequence (Guttman et al., 2014).

An ongoing change in gene alleles especially effector genes, provides plant pathogens with the ability to evade detection while optimizing or maintaining virulence. To ensure survival, pathogens may have to evolve new effectors to successfully colonize and infect a new host target. Adaptation to hosts is believed to be enabled by compartmentalization of effector genes within the genome. Plant pathogenic fungi and oomycetes contain gene-sparse genomic regions that are exceedingly enriched in repetitive elements and putative effector genes (Raffaele and Kamoun, 2012). The movement of transposable elements (TEs) within these genome compartments results in gene duplication, horizontal gene transfer and gene loss, all of which contribute to virulence factor evolution (Lo Presti et al., 2015). For example, the fungal pathogen L. maculans has an unusual genome structure compared to other pathogenic fungi in that it contains alternating GC and AT-rich blocks termed GC- and AT-isochores. The GC-isochore regions are enriched with housekeeping genes, whereas the AT-isochores are relatively gene-sparse, enriched in TEs which are truncated and further reduced by repeat-induced point mutations (RIP). The ATisochore harbors $\sim 122$ genes encoding small secreted proteins (Rouxel et al., 2011), which also includes the conditionally dispensable chromosome (Soyer et al., 2014). In F. oxysporum, all known effector genes are found in one of its four dispensable chromosomes (Ma et al., 2010) and in P. infestans effector genes are located in highly plastic genomic regions, enriched in TEs (Haas et al., 2009).

Horizontal gene transfer (HGT) is another important mechanism by which effector diversification occurs in fungal pathogens. One particular study conducted on $M$. oryzae revealed that the Avr-Pita effector had been translocated several times via mobile elements. The authors suggested that multiple translocations implicate deletions and recoveries mediated via parasexual transfer among individual isolates (Chuma et al., 2011). In addition to intraspecies genetic transfer an HGT event was also reported between different species documented by the transfer of ToxA along with hAT transposase from the wheat blotch pathogen Stagonospora nodorum to Pyrenophora tritci-repentis, which is the causal agent of tan spot in wheat (Friesen et al., 2006). These studies highlight how selection can influence specific evolutionary changes leading toward diversification of virulence-promoting effectors.

\section{FUNCTION OF CHARACTERIZED FUNGAL EFFECTORS IN BIOTROPHS AND HEMIBIOTROPHS}

Unlike bacterial and oomycete effectors, a limited number of fungal effectors have been functionally characterized. The primary obstacles in fungal effector research derive from difficulties associated with manipulating fungi in a laboratory setting, in particular obligate biotrophs such as rust fungi. Adding to these challenges is the fact that many effector mutants display no associated phenotype, likely due to functional redundancy, poor assay systems or the inability to accurately measure small changes in phenotype. However, technologies such as bimolecular fluorescent complementation (BiFC) (Kerppola, 2008; Kodama and $\mathrm{Hu}, 2012$ ), immunocolocalization (Dunn et al., 2011) yeast-two hybrid systems (Bruckner et al., 2009) and gene expression assays have significantly advanced our understanding of the functional roles of secreted fungal effectors. In this section, we will discuss the function of biotrophic and hemibiotrophic fungal effectors and emphasize which of the above mentioned techniques were used to further understand in planta effector localization, or protein-protein interactions. 


\section{Effectors Identified in Biotrophs}

To date, functional analysis of effectors from biotrophic pathogens including $U$. maydis and C. fulvum are among the most extensively studied. Much has been revealed about the effectors in the maize pathogen $U$. maydis. With a relatively small genome of $20.5 \mathrm{Mb}, \sim 50$ secreted proteins have been predicted, $50 \%$ of which are novel (Kamper et al., 2006; Koeck et al., 2011; Djamei and Kahmann, 2012). Many of these novel genes are localized within gene clusters, and appear to be upregulated during host colonization, and encode effectors that have virulence function (Kamper et al., 2006; Schirawski et al., 2010). As shown in Table 1, five effector proteins, Pep1, Pit2, Cmu1, Tin2, and See1 have been well-characterized.

Pep1 (protein essential for penetration 1) is a small (178 amino acīids) secreted effector of $U$. maydis and related smut fungi that has been shown to accumulate in the apoplast. Doehlemann et al. (2009) confirmed the presence of Pep1 within the apoplastic spaces within the leaves, in addition to finding protein accumulation at sites of cell-to-cell passage using in vivo immunocolocalization (Doehlemann et al., 2009). Inoculation of leaves with pep1 deletion mutants showed a failure to establish compatible interactions along with large necrotic patches. Interestingly, the $\Delta p e p 1$ mutants were defective for penetration of the initial epidermal cell and cell-to-cell spread. Pep1 has also been shown to be required to overcome extensive host resistance. Using bimolecular fluorescence complementation (BiFC) a direct interaction between the Pep1 protein and the maize defense peroxidase POX12 was established. It appears that Pep1 is able to suppress plant defense mechanisms through scavenging reactive oxygen species (ROS) (Hemetsberger et al., 2012). Interestingly, a recent report further supported the role of Pep1, as it was shown to be necessary for inducing hypersensitive response that displayed necrotic cell death features (Hof et al., 2014).

Pit2 (protein involved in tumors 2) is a secreted, apoplastic effector of $U$. maydis that is required for virulence; studies have shown that a mutation within the pit2 gene results in attenuation of tumor formation (Doehlemann et al., 2011). A recent study illustrated through the utilization of a yeast-two hybrid system that Pit2 directly interacts with maize cysteine proteases. Using a complementary approach, these researchers illustrated that when the recombinant Pit2 protein was co-inoculated with cysteine protease (CP2), the protease activity was significantly reduced, indicating that Pit2 inhibits the proteases activity via direct interaction. It was also noted that the $\mathrm{CP} 2$ protease utilized in the study was recently identified in the leaf apoplasts as an important factor required for Salicylic acid (SA)-associated defense (Mueller et al., 2013), suggesting the importance of Pit 2 in virulence.

Cmul is an effector that is translocated into the host cell. The cmul gene of $U$. maydis is most strongly induced during plant colonization, leading to an abundance of Cmul protein accumulation detected within the apoplast (Djamei et al., 2011). Through complementation analysis in yeast, along with in vitro enzymatic assays, Cmul was shown to be a chorismate mutase. As the branching metabolite of the shikimate pathway, chorismate is the precursor for synthesis of aromatic amino acids and the plant defense hormone salicylic acid. Data obtained from utilizing a two hybrid system indicated that Cmul can form heterodimers with the plastidic as well as the cytosolic forms of plant chorismate mutase (Eberhard et al., 1996; Djamei et al., 2011). Immunocolocalization studies illustrated that Cmu1 was located within the cytosol after translocation into the host plant cell, where the flow of chorismate was redirected through potential cooperation between the cytosolic maize chorismate mutase along with Cmul, leading to a reduction in available chorismate for salicylic acid biosynthesis (Eberhard et al., 1996). Interestingly, Cmul has the ability to spread locally to neighboring yet uninfected host cells (most likely via plasmodesmata), which the authors suggest is a form of metabolic priming leading to lower salicylic acid levels, allowing cells to prepare for impending colonization by U. maydis (Eberhard et al., 1996).

The effector Tin2 (Tumor inducing 2) is part of the largest cluster of effectors identified in $U$. maydis and was shown to be responsible for anthocyanin induction during biotrophic phase and have a role in virulence (Brefort et al., 2009). Tin2 localization was shown using confocal microscopy, which illustrated the accumulation of the protein around the fungal hyphae, which is secreted into the apoplast and functions within the cytosol (Tanaka et al., 2014). Inside the plant, the Tin2 protein appears to interact with the protein TTK1 (Tin2-targeting kinase1), a maize protein kinase that regulates the anthocyanin biosynthetic pathway (Tanaka et al., 2014). The interaction between Tin2 and TKK1 was observed using a yeast two-hyrbid screen, where the region of contact between the two proteins coincided with a variable region containing a phosphodegron motif, which is the target for the ubiquitin ligase complex that leads to protein degredation through the ubiquitin-proteasome system (Ravid and Hochstrasser, 2008; Spoel et al., 2009). (Tanaka et al., 2014) illustrated that the Tin 2 protein protects the active kinase against ubiquitination as the full length TKK1 was only detectable on SDS-PAGE when co-expressed in planta with a functional Tin2 protein. The stabilization of TKK1 via Tin2 appears to positively stimulate the production of anthocyanin in infected tissue and suppress lignin biosynthesis, a common defense pathway (Tanaka et al., 2014).

The U. maydis effector protein See1 (Seedling efficient effector 1 ) is recognized as an organ-specific effector that induces tumor expansion specifically on maize leaves (Redkar et al., 2015). It appears that this protein is expressed in the nucleus and cytoplasm of maize as live cell imaging and immunolabeling using transmission electron microscopy were able to detect the See1-mCherry tagged protein within these two areas of the plant cell (Redkar et al., 2015). See1 is required for reactivation of DNA synthesis, which is an important step for tumor progression in maize leaf cells (Walbot and Skibbe, 2010). Through yeast-two hybrid analysis, it was shown that this protein interacts with maize homolog of SGT1 (Suppressor of G2 allele of skp1), a factor that has been shown to act in cell cycle progression in yeast (Dubacq et al., 2002) and an essential component of innate immunity in plant and animals (Shirasu, 2009; Zhang et al., 2010). Further analysis of this interaction illustrated that the See1 protein restricts MAPK-triggered phosphorylation of maize SGT1, which could potentially modulate the immune responses 
and DNA reactivation synthesis within leaf cells (Redkar et al., 2015).

C. fulvum produces at least 10 different effector proteins (Table 1), three of which have been functionally characterized; Avr4, Ecp6, and Avr2. The Avr4 and Ecp6 effectors are involved in suppression of chitin-induced PTI. Avr4 binds to chitin in the fungal cell wall, which protects the fungi against hydrolysis caused by plant chitinases (van den Burg et al., 2006). The Ecp6 effector appears to sequester chitin oligosaccharides, which are released by cell walls during hyphal invasion, allowing the suppression of host immunity (Bolton et al., 2008; de Jonge et al., 2010). A study focused on structural formation of the Ecp6 protein illustrated that two of the three LysM protein domains undergo ligand-induced dimerization, resulting in a high affinity chitin-binding pocket, while the third LysM domain binds to chitin with lower affinity. The authors suggest that binding of this protein out-competes the plant chitin receptor by interfering with its dimerization (Sanchez-Vallet et al., 2013).

The Avr2 effector produced by C. fulvum specifically targets secreted cysteine proteases, similar to Cmul in U. maydis. One particular study using heterologous expression of Avr2 in A. thaliana illustrated an enhanced susceptibility in planta toward extracellular fungal pathogens, which included $B$. cinerea and Verticillium dahlia. Interestingly, microarray analysis demonstrated that Avr2 expression generated global changes in the transcriptome reflecting pathogen challenge. Through monitoring protease activity, Avr2 was found to inhibit multiple extracellular Cys proteases, including Rcr3 and its close relative Pip1. In addition, infection by C. fulvum was significantly reduced when Avr2 was silenced. Collectively these findings illustrate that Avr2 not only inhibits several Cys proteases required for plant basal defense but it also functions as a virulence factor (van Esse et al., 2008).

\section{Effectors Identified in Hemibiotrophs}

Hemibiotrophic fungi have a distinct lifestyle wherein they combine a biotrophic phase with a nectrotrophic phase. In this section, we will focus on two hemibiotrophs, M. oryzae and L. maculans.

A whole genome draft sequence of the M. oryzae isolate 7015 revealed a genome size of $37.8 \mathrm{Mb}$, with nucleotides encoding $\sim 11,109$ proteins (Dean et al., 2005). From the predicted proteome, 1309 genes were predicted to encode secreted proteins (Yoshida et al., 2009). As shown in Table 1, $\sim 16$ different effectors have been cloned or characterized to date. Recently, map-based cloning of AvrPib was reported (Zhang et al., 2015), adding another Avr-type effector to the repertoire. MC69 was also shown to be required for pathogenicity; however no evidence was provided to show that this protein suppresses or interferes with plant defense responses (Saitoh et al., 2012). The best characterized effectors to date include SLP1, AvrPiz-t, and ACE1.

SLP1 is a secreted LysM protein that has been shown to be required for M. oryzae virulence and is similar to the Ecp6 chitin binding protein found in C. fulvum. In a study conducted by Mentlak et al. (2012) live-cell imaging of the GFP-tagged SLP1 illustrated that the protein accumulated at the plant-fungus interface upon rice infection and accrued at the tips of the invading hypae when fungus moved into invading cells (Mentlak et al., 2012). Deletion in the SLP1 gene reduced the ability of $M$. oryzae to cause disease, which was associated with the inability to proliferate within the host tissues, rather than reducing production of structures required for successful penetration. In a high stringency yeast two-hybrid analysis, SLP1 monomers appeared to associate with one another, suggesting that this protein forms oligomers (Mentlak et al., 2012). The protein was also shown to bind specifically to chitin as purified forms of the protein only co-precipitated with chitin beads or insoluble crab chitin, and not with any other tested polysaccharide (Mentlak et al., 2012). In addition to these findings, the authors determined that SLP1 was able to out-compete the rice PRR chitin elicitor binding protein (CEBiP) for chitin binding when challenged in a competition assay, and suppress chitin-induced oxidative burst,. These findings illustrate that SLP1 binds directly to chitin thereby suppressing chitin-triggered immune response in rice. However, it seems that this function is reliant on the presence of $\mathrm{CEBiP}$, as rice plants silenced with CEBiP RNAi generated disease symptoms when inoculated with the $\Delta$ slp1 mutant (Mentlak et al., 2012). Taken together, the key function of SLP1 as a suppressor of chitin-triggered defense response appears to be reliant on the interaction between SLP1 and CEBiP, which determines the progression of rice blast disease.

AvrPiz-t is a cytoplasmic (Avr-type) effector that has been shown to target the cytosolic rice R-gene (Zhou et al., 2006; Li et al., 2009). AvrPiz-t contributes to disease development in rice when it lacks the corresponding resistance protein Piz-t. Expression of AvrPiz-t in transgenic plant lines illustrated that PTI was suppressed, leading to a reduction in ROS and enhanced susceptibility to M. oryzae (Park et al., 2012). A yeast two-hybrid screen identified the interaction between AvrPiz-t with a rice RING E3 ubiquitin ligase APIP6. Ubiquitination of AvrPiz-t by APIP6 was visualized via immune-blotting, and it was shown that after ubiquitination AvrPiz-t-mediated suppression of APIP6 activity occurred (Park et al., 2012).

ACE1, another avirulence gene found in M. oryzae has been shown to be upregulated during initiation of infection. ACE1 is not predicted to be secreted or localized to the plant cell cytoplasm, suggesting that the protein itself is not the actual effector but that ACE1 is responsible for the synthesis of an effector that is recognized by the plant R-protein (Bohnert et al., 2004). However, the mechanism by which this occurs has yet to be elucidated.

In L. maculans, a total of 122 candidate effectors have been predicted (Rouxel et al., 2011). In terms of Avr effectors, 11 avirulence genes (Avr) termed AvrLm1, 2, 3, 4, 5, 6, 7, 9, 11, AvrLepR1, and AvrLmJ1 have been identified (Balesdent et al., 2002, 2005; Ghanbarnia et al., 2012; Van de Wouw et al., 2014). All of the proteins produced by these genes are known as effectors; small, secreted, cysteine-rich proteins that are nonhomologous to any other known L. maculans proteins. In plants lacking the corresponding R-protein, the above mentioned Avr effector proteins contribute to disease development; however very little is known about their mechanistic function and whether they are involved in plant immune suppression or virulence specifically. Recently a new study illustrated that the 
AvrLm4-7 effector was strongly required for virulence (Nováková et al., 2015). Through analysis of plant hormone concentrations, defense gene transcription and ROS accumulation, the authors were able to show that various components of the plant immune system were affected after inoculation with an L. maculans isolate lacking a functional AvrLm4-7 allele. Plants inoculated with the isolate carrying a functional AvrLm4-7 gene produced larger cotyledon lesion than the control group isolates that did not harbor an active allele. Interestingly, incompatible interactions due to recognition of AvrLm4-7 by Rlm4 revealed strong early induction of SA and Ethylene (ET)-dependent signaling pathways, which was also previously shown to occur upon recognition of AvrLm1 by Rlm1 (Šašek et al., 2012; Nováková et al., 2015). Through LC-MS/MS chromatography and RTqPCR analysis (Nováková et al., 2015) determined that an active AvrLm4-7 allele causes suppression of SA-signaling, affecting not only its biosynthesis, but also reducing the expression of the SA-related marker gene $P R 1$. The same situation appears to hold true in terms of ET-signaling, where AvrLm4-7 reduces the expression of ACS 2 and HEL expression, two ET-responsive genes. These findings together with a recent report illustrating that AvrLm4-7 is translocated into the plant cell (Blondeau et al., 2015) suggest that the plant SA and/or ET hormone signaling pathways, which are critical for induction of the plant defense response (Wang and Irving, 2011), are the primary targets of AvrLm4-7.

\section{CRISPR/CAS9: A NEW TECHNIQUE TO ACCELERATE OUR UNDERSTANDING OF EFFECTOR FUNCTION}

From the findings described above, it is apparent that a great deal of progress has been made toward understanding the role of fungal effectors. The most common approach utilized to elucidate the function of these genes involves reverse genetics, where the functional gene is replaced by an antibiotic selection marker, or deleted through homologous recombination. Effector genes in $U$. maydis and $M$. oryzae, as well as pathogenicity genes in L. maculans have been successfully deleted using this method (Hemetsberger et al., 2012; Mentlak et al., 2012; Mueller et al., 2013; Feng et al., 2014; Lo Presti et al., 2015). Gene silencing through RNAi has also been used in a number of fungi (Panwar et al., 2013; Petre et al., 2014; Soyer et al., 2014; Whigham et al., 2015; Yin et al., 2015). Although these methods have proven extremely useful, it has become apparent that there is an increasing need in effector research for techniques that can address effector gene redundancy and function within a large protein family. For studies such as these, we are currently limited in terms of fungal selection markers, where it becomes increasingly difficult to generate strains carrying multiple mutations within defined sites. One particular method that is used to recycle antibiotic markers is called the FLPFRT recombination technique. FLP is a site-specific recombinase, which catalyzes recombination between two directly oriented FRT sites, leading to excision of the intervening DNA segment. Because the antibiotic selection marker is located on the intervening DNA segment, the end result is an unmarked gene disruption (Wirth et al., 2007). In U. maydis, this approach represents one of the best ways to introduce multiple mutations within the genome without utilizing all available selection markers; however a number of retro-transformation cycles followed by growth cycles to stimulate the loss of the marker are often required (Khrunyk et al., 2010).

The clustered regularly interspaced short palindromic repeat (CRISPR)-Cas9 system was originally identified in bacteria and archaea as a defense mechanism to prevent the invasion of foreign DNA from phage or plasmids (Barrangou et al., 2007). The CRISPR/Cas9 system has been adapted for use in a number of genome editing applications in both eukaryotes and prokaryotes (Jinek et al., 2012; Cong et al., 2013; Jiang et al., 2013; Doudna and Charpentier, 2014; Nissim et al., 2014; Sander and Joung, 2014). The adapted system consists of a Cas9 nuclease, which is guided to a specific target site by a single guide RNA (sgRNA). The nuclease then generates a double stranded break (DSB) at the desired target site within the genome. The DSB within the DNA initiates the repair mechanism (non-homologous end joining pathway) resulting in short deletions or substitutions, which may cause frameshifts or generate premature stop codons within the ORF of the target DNA (Doudna and Charpentier, 2014). Application of the CRISPR/Cas9 system depends on the expression of the cas 9 gene from Streptococcus pyogenes and the ability of the sgRNA to express and fold into the secondary structure necessary for interaction with Cas9 nuclease inside the nucleus.

CRISPR/Cas9-based technologies have emerged as an effective way to generate unmarked mutations in several organisms (Sander and Joung, 2014), including Saccharomyces cereviseae (DiCarlo et al., 2013), Trichoderma reesei (Liu et al., 2015), M. oryzae (Arazoe et al., 2015), and Neurospora crassa (Matsuura et al., 2015). One particular group was able to show that CRISPR/Cas9 could be modified to enable disruption and replacement of an effector gene in the oomycete $P$. sojae (Fang and Tyler, 2015). In each of the mutations the authors examined, short indels were located specifically at the Cas9 cleavage site, and deletions of one, three and six base-pairs were observed within the target regions providing evidence regarding the effectiveness of this system. Nodvig and colleagues developed a CRISPR/Cas9 system that allows RNA-guided mutagenesis by transforming a target fungus with a single plasmid. This approach was further modified allowing enhanced functionality in a broader range of filamentous fungi through the use of strong promoters from Aspergillus niger for cas 9 and sgRNA expression (Nodvig et al., 2015). More intriguingly, the CRISPR/Cas9 system has high efficiency in targeting multiple unrelated genes using several sgRNA, as shown in the yeast Saccharomyces cerevisiae (Cong et al., 2013), the filamentous fungus T. reesei (Liu et al., 2015) and two plant systems, namely rice and Arabidopsis (Endo et al., 2015; Zhang et al., 2015).

Clearly, the CRISPR/Cas9 "craze" has led to a plethora of useful tools that target not only single genes, but multiple gene targets, which will be extremely useful for effector research. The most valuable attribute of the CRISPR/Cas9 systems is its versatility, where the tools can be used to specifically 
target genes for mutagenesis in many organisms. Certainly, this system will transform and improve biological research, leading to many new discoveries in gene regulation and function. Nevertheless, this system is still in its infancy and as such several aspects need to be refined, including offtargeting and expression of the components within the desired host.

\section{CONCLUSION: FUTURE CHALLENGES}

We have gained a wealth of knowledge toward understanding plant-pathogen interactions over the past several decades. Research has shown that effector proteins play a significant role in the ability of fungal pathogens to establish a compatible interaction with the host plant, and in some cases have confirmed their involvement as virulence factors. We have working methods for developing mutations within single genes, and with the introduction of CRISPR/Cas9 technology, we now have the capability to target multiple genes without the use of markers. This system will significantly improve our ability to target redundant or related effector genes at one time, perhaps providing a definitive or visual phenotype that will provide insight into effector function. Despite our improved knowledge in this area, some important factors remain unresolved. Many

\section{REFERENCES}

Ali, S., Laurie, J. D., Linning, R., Cervantes-Chavez, J. A., Gaudet, D., and Bakkeren, G. (2014). An immunity-triggering effector from the Barley smut fungus Ustilago hordei resides in an Ustilaginaceae-specific cluster bearing signs of transposable element-assisted evolution. PLoS Pathog. 10:e1004223.doi: 10.1371/journal.ppat.1004223

Arazoe, T., Miyoshi, K., Yamato, T., Ogawa, T., Ohsato, S., Arie, T., et al. (2015). Tailor-made CRISPR/Cas system for highly efficient targeted gene replacement in the rice blast fungus. Biotechnol. Bioeng. 112, 2543-2549. doi: 10.1002/bit.25662

Armstrong, M. R., Whisson, S. C., Pritchard, L., Bos, J. I., Venter, E., Avrova, A. O., et al. (2005). An ancestral oomycete locus contains late blight avirulence gene Avr3a, encoding a protein that is recognized in the host cytoplasm. Proc. Natl. Acad. Sci. U.S.A. 102, 7766-7771. doi: 10.1073/pnas.0500113102

Asai, S., and Shirasu, K. (2015). Plant cells under siege: plant immune system versus pathogen effectors. Curr. Opin. Plant Biol. 28, 1-8. doi: 10.1016/j.pbi.2015.08.008

Balesdent, M. H., Attard, A., Kuhn, M. L., and Rouxel, T. (2002). New avirulence genes in the phytopathogenic fungus Leptosphaeria maculans. Phytopathology 92, 1122-1133. doi: 10.1094/PHYTO.2002.92.10.1122

Balesdent, M. H., Barbetti, M. J., Li, H., Sivasithamparam, K., Gout, L., and Rouxel, T. (2005). Analysis of Leptosphaeria maculans race structure in a worldwide collection of isolates. Phytopathology 95, 1061-1071. doi: 10.1094/PHYTO-951061

Balesdent, M. H., Fudal, I., Ollivier, B., Bally, P., Granaubert, J., Chevre, A., et al. (2013). The dispensable chromosome of Leptosphaeria maculans shelters an effector gene conferring avirulence towards Brassica rapa. New Phytol. 198, 889-898. doi: 10.1111/nph.12178

Barrangou, R., Fremaux, C., Deveau, H., Richards, M., Boyaval, P., Moineau, S., et al. (2007). CRISPR-Cas9 provides acquired resistance against viruses in prokaryotes. Science (New York, N.Y.) 315, 1709-1712. doi: $10.1126 /$ science. 1138140

Blondeau, K., Blaise, F., Graille, M., Kale, S. D., Linglin, J., Ollivier, B., et al. (2015). Crystal structure of the effector AvrLm4-7 of Leptosphaeria maculans reveals fungal effectors have been shown to function primarily within the plant cytosol, yet lack translocation signals within the primary amino acid sequence. This brings into question how effectors are targeted to and taken across the plasma membrane of the plant cell? Although some host targeting sequence motifs have been identified in oomycetes, most fungi do not share this common feature. Moreover, the low sequence homologies among these fungal proteins make it difficult to predict similar features. However, the rapid development of next-generation sequencing tools and new bioinformatics algorithms and pipelines will provide new whole-genome information for both biotrophic and hemibiotrophic fungi. Given the large numbers of effector candidates, research will be a challenge. However, with the continuous development of new tools and techniques we will undoubtedly move toward exceptional opportunities for investigating the roles of fungal pathogen effectors in plantpathogen interactions.

\section{AUTHOR CONTRIBUTIONS}

Concept of article by WD. Also went through all research papers and finalized the review. CS did the undertaking of researching on the topic and writing the review. TD and $\mathrm{MB}$ read the manuscript and gave input on improvements. insights into its translocation into plant cells and recognition by resistance proteins. Plant J. 83, 610-624. doi: 10.1111/tpj.12913

Bohnert, H. U., Fudal, I., Dioh, W., Tharreau, D., Notteghem, J. L., and Lebrun, M. H. (2004). A putative polyketide synthase/peptide synthetase from Magnaporthe grisea signals pathogen attack to resistant rice. Plant Cell 16, 2499-2513. doi: 10.1105/tpc.104.022715

Bolton, M. D., van Esse, H. P., Vossen, J. H., de Jonge, R., Stergiopoulos, I., Stulemeijer, I. J., et al. (2008). The novel Cladosporium fulvum lysin motif effector Ecp6 is a virulence factor with orthologues in other fungal species. Mol. Microbiol. 69, 119-136. doi: 10.1111/j.1365-2958.2008.06270.x

Bos, J. I., Armstrong, M. R., Gilroy, E. M., Boevink, P. C., Hein, I., Taylor, R. M., et al. (2010). Phytophthora infestans effector AVR3a is essential for virulence and manipulates plant immunity by stabilizing host E3 ligase CMPG1. Proc. Natl. Acad. Sci. U.S.A. 107, 9909-9914. doi: 10.1073/pnas.0914408107

Boutemy, L. S., King, S. R., Win, J., Hughes, R. K., Clarke, T. A., Blumenschein, T. M., et al. (2011). Structures of Phytophthora RXLR effector proteins: a conserved but adaptable fold underpins functional diversity. J. Biol. Chem. 286, 35834-35842. doi: 10.1074/jbc.M111.262303

Bozkurt, T. O., Schornack, S., Win, J., Shindo, T., Ilyas, M., Oliva, R., et al. (2011). Phytophthora infestans effector AVRblb2 prevents secretion of a plant immune protease at the haustorial interface. Proc. Natl. Acad. Sci. U.S.A. 108, 20832-20837. doi: 10.1073/pnas.1112708109

Brefort, T., Doehlemann, G., Mendoza-Mendoza, A., Reissmann, S., Djamei, A., and Kahmann, R. (2009). Ustilago maydis as a pathogen. Annu. Rev. Phytopath. 47, 423-445. doi: 10.1146/annurev-phyto-080508081923

Bruckner, A., Polge, C., Lentze, N., Auerbach, D., and Schlattner, U. (2009). Yeasttwo hybrid system, a powerful tool for systems biology. Int. J. Mol. Sci. 10, 2763-2788. doi: 10.3390/ijms10062763

Cao, T., Kim, Y. M., Kav, N. N. V., and Strelkov, S. E. (2009). A proteomic evaluation of Pyrenophora tritici-repentis, causal agent of tan spot of wheat, reveals major differences between virulent and avirulent isolates. Proteomics 9 , 1177-1196. doi: 10.1002/pmic.200800475

Cao, Y., Liang, Y., Tanaka, K., Nguyen, C. T., Jedrezjczak, R. P., Joachimiak, A., et al. (2014). The kinase LYK5 is a major chitin receptor in Arabidopsis and 
forms a chitin-induced complex with related kinase CERK1. eLife 3:e03766. doi: 10.7554/eLife.03766

Catanzariti, A. M., Dodds, P. N., Lawrence, G. J., Ayliffe, M. A., and Ellis, J. G. (2006). Haustorially expressed secreted proteins from flax rust are highly enriched for avirulence elicitors. Plant Cell 18, 243-256. doi: 10.1105/tpc.105.035980

Cesari, S., Thilliez, G., Ribot, C., Chalvon, V., Michel, C., Jauneau, A., et al. (2013). The rice resistance protein pair RGA4/RGA5 recognizes the Magnaporthe oryzae effectors Avr-Pia and Avr1-CO39 by direct binding. Plant Cell 25, 1463-1481. doi: 10.1105/tpc.112.107201

Chuma, I., Isobe, C., Hotta, Y., Ibaragi, K., Futamata, N., Kusaba, M., et al. (2011). Multiple translocation of the AVR-Pita effector gene among chromosomes of the rice blast fungus Magnaporthe oryzae and related species. PLoS Pathog. 7:e1002147. doi: 10.1371/journal.ppat.1002147

Cong, L., Ran, F. A., Cox, D., Lin, S., Barretto, R., Habib, N., et al. (2013). Multiplex genome engineering using CRISPR/Cas systems. Science (New York, N.Y.) 339, 819-823. doi: 10.1126/science. 1231143

Cui, H., Tsuda, K., and Parker, J. E. (2015). Effector-triggered immunity: from pathogen perception to robust defense. Annu. Rev. Plant Biol. 66, 487-511. doi: 10.1146/annurev-arplant-050213-040012

de Jonge, R., Bolton, M. D., and Thomma, B. P. (2011). How filamentous pathogens co-opt plants: the ins and outs of fungal effectors. Curr. Opin. Plant Biol. 14, 400-406. doi: 10.1016/j.pbi.2011.03.005

de Jonge, R., van Esse, H. P., Kombrink, A., Shinya, T., Desaki, Y., Bours, R., et al. (2010). Conserved fungal LysM effector Ecp6 prevents chitintriggered immunity in plants. Science (New York, N.Y.) 329, 953-955. doi: 10.1126/science. 1190859

De Wit, P. J., Brandwagt, B. F., van den Burg, H. A., Cai, X., van der Hoorn, R. A., de Jong, C. F., et al. (2002). The molecular basis of co-evolution between Cladosporium fulvum and tomato. Antonie Van Leeuwenhoek 81, 409-412. doi: 10.1023/A:1020553120889

De Wit, P. J., Buurlage, M. B., and Hammond, K. E. (1986). The occurrence of host-, pathogen- and interaction-specific proteins in the apoplast of Cladosporium fulvum (syn. Fulvia fulva) infected tomato leaves. Physiol. Mol. Plant Pathol. 29, 159-172. doi: 10.1016/S0048-4059(86)80018-2

Dean, R. A., Talbot, N. J., Ebbole, D. J., Farman, M. L., Mitchell, T. K., Orbach, M. J., et al. (2005). The genome sequence of the rice blast fungus Magnaporthe grisea. Nature 434, 980-986. doi: 10.1038/nature03449

DiCarlo, J. E., Norville, J. E., Mali, P., Rios, X., Aach, J., and Church, G. M. (2013). Genome engineering in Saccharomyces cerevisiae using CRISPR-Cas systems. Nucleic Acids Res. 41, 4336-4343. doi: 10.1093/nar/gkt135

Dixon, M. S., Jones, D. A., Keddie, J. S., Thomas, C. M., Harrison, K., and Jones, J. D. (1996). The tomato Cf-2 disease resistance locus comprises two functional genes encoding leucine-rich repeat proteins. Cell 84, 451-459. doi: 10.1016/S0092-8674(00)81290-8

Djamei, A., and Kahmann, R. (2012). Ustilago maydis: dissecting the molecular interface between pathogen and plant. PLoS Pathog. 8:e1002955. doi: 10.1371/journal.ppat.1002955

Djamei, A., Schipper, K., Rabe, F., Ghosh, A., Vincon, V., Kahnt, J., et al. (2011). Metabolic priming by a secreted fungal effector. Nature 478, 395-398. doi: 10.1038 /nature 10454

Dodds, P. N., and Rathjen, J. P. (2010). Plant immunity: towards an integrated view of plant-pathogen interactions. Nat. Rev. 11, 539-548. doi: 10.1038/nrg2812

Dodds, P. N., Lawrence, G. J., Catanzariti, A. M., Ayliffe, M. A., and Ellis, J. G. (2004). The Melampsora lini AvrL567 avirulence genes are expressed in haustoria and their products are recognized inside plant cells. Plant Cell 16, 755-768. doi: 10.1105/tpc.020040

Doehlemann, G., Reissmann, S., Assmann, D., Fleckenstein, M., and Kahmann, R. (2011). Two linked genes encoding a secreted effector and a membrane protein are essential for Ustilago maydis -induced tumour formation. Mol. Microbiol. 81, 751-766 doi: 10.1111/j.1365-2958.2011.07728.x

Doehlemann, G., van der Linde, K., Assmann, D., Schwammbach, D., Hof, A., Mohanty, A., et al. (2009). Pep1, a secreted effector protein of Ustilago maydis, is required for successful invasion of plant cells. PLoS Pathog. 5, e1000290. doi: 10.1371/journal.ppat. 1000290

Dong, S., Qutob, D., Tedman-Jones, J., Kuflu, K., Wang, Y., Tyler, B. M., et al. (2009). The Phytophthora sojae avirulence locus Avr3c encodes a multi-copy
RXLR effector with sequence polymorphisms among pathogen strains. PLoS One 4:e5556. doi: 10.1371/journal.pone.0005556

Dong, S., Yin, W., Kong, G., Yang, X., Qutob, D., Chen, Q., et al. (2011). Phytophthora sojae avirulence effector Avr3b is a secreted NADH and ADPribose pyrophosphorylase that modulates plant immunity. PLoS Pathog. 7:e1002353. doi: 10.1371/journal.ppat.1002353

Dou, D., Kale, S. D., Liu, T., Tang, Q., Wang, X., Arredondo, F. D., et al. (2010). Different domains of Phytophthora sojae effector Avr4/6 are recognized by soybean resistance genes Rps4 and Rps6. Mol. Plant Microbe Interact. 23, 425-435. doi: 10.1094/MPMI-23-4-0425

Dou, D., Kale, S. D., Wang, X., Jiang, R. H. Y., Bruce, N. A., Arredondo, F. D., et al. (2008a). RXLR-mediated entry of Phytophthora sojae effector Avrlb into soybean cells does not require pathogen-encoded machinery. Plant Cell 20, 1930-1947. doi: 10.1105/tpc.107.056093

Dou, D., Kale, S. D., Wang, X., Chen, Y., Wang, Q., Wang, X., et al. (2008b). Carboxy-terminal motifs common to many oomycete RXLR effectors are required for avirulence and suppression of BAX-mediated programmed cell death by Phytophthora sojae effector Avrlb. Plant Cell 20, 1118-1133. doi: 10.1105/tpc.107.057067

Doudna, J. A., and Charpentier, E. (2014). Genome editing. The new frontier of genome engineering with CRISPR-Cas9. Science (New York, N.Y.) 346, 1258096. doi: 10.1126/science. 1258096

Dubacq, C., Guerois, R., Courbeyrette, R., Kitagawa, K., and Mann, C. (2002). Sgtlp contributes to cyclic AMP pathway activity and physically interacts with the adenylyl cyclase Cyr1p/Cdc35p in budding yeast. Eukaryotic Cell 1, 568-582. doi: 10.1128/EC.1.4.568-582.2002

Dunn, K. W., Kamocka, M. M., and McDonald, J. H. (2011). A practical guide to evaluating colocalization in biological microscopy. Am. J. Physiol. Cell Physiol. 300, C723-C742. doi: 10.1152/ajpcell.00462.2010

Duplessis, S., Cuomo, C. A., Lin, Y. C., Aerts, A., Tisserant, E., VeneaultFourrey, C., et al. (2011). Obligate biotrophy features unraveled by the genomic analysis of rust fungi. Proc. Natl. Acad. Sci. U.S.A. 108, 9166-9171. doi: 10.1073/pnas.1019315108

Eberhard, J., Ehrler, T. T., Epple, P., Felix, G., Raesecke, H. R., Amrhein, N., et al. (1996). Cytosolic and plastidic chorismate mutase isozymes from Arabidopsis thaliana: molecular characterization and enzymatic properties. Plant J. 10, 815-821. doi: 10.1046/j.1365-313X.1996.10050815.x

Endo, M., Mikami, M., and Toki, S. (2015). Multigene knockout utilizing off-target mutations of the CRISPR/CAS9 system in rice. Plant Cell Physiol. 56, 41-47. doi: $10.1093 / \mathrm{pcp} / \mathrm{pcu} 154$

Fang, Y., and Tyler, B. M. (2015). Efficient disruption and replacement of an effector gene in the oomycete Phytophthora sojae using CRISPR/CAS9. Mol. Plant Pathol. 17, 127-139. doi: 10.1111/mpp.12318

Farman, M. L., and Leong, S. A. (1998). Chromosome walking to the AVR1-CO39 avirulence gene of Magnaporthe grisea: discrepancy between the physical and genetic maps. Genetics 150, 1049-1058.

Feng, J., Zhang, H., Strelkov, S. E., and Hwang, S. F. (2014). The LmSNF1 gene is required for pathogenicity in the canola blackleg pathogen Leptosphaeria maculans. PLoS One 9:e92503. doi: 10.1371/journal.pone.00 92503

Flor, H. H. (1956). The complementary systems in flax and flax rust. Adv. Genet. 8, 29-54. doi: 10.1016/S0065-2660(08)60498-8

Friesen, T. L., Stukenbrock, E. H., Liu, Z., Meinhardt, S., Ling, H., Faris, J. D., et al. (2006). Emergence of a new disease as a result of interspecific virulence gene transfer. Nat. Genet. 38, 953-956. doi: 10.1038/ng1839

Fudal, I., Bohnert, H. U., Tharreau, D., and Lebrun, M. H. (2005). Transposition of MINE, a composite retrotransposon, in the avirulence gene ACE1 of the rice blast fungus Magnaporthe grisea. Fungal Genet. Biol. 42, 761-772. doi: 10.1016/j.fgb.2005.05.001

Fudal, I., Ross, S., Brun, H., Besnard, A. L., Ermel, M., Kuhn, M. L., et al. (2009). Repeat-induced point mutation (RIP) as an alternative mechanism of evolution towards virulence in Leptosphaeria maculans. Mol. Plant Microbe Interact. 22, 932-941. doi: 10.1094/MPMI-22-8-0932

Fudal, I., Ross, S., Gout, L., Blaise, F., Kuhn, M. L., Eckert, M. R., et al. (2007). Heterochromatin-like regions as ecological niches for avirulence genes in the Leptosphaeria maculans genome: map-based cloning of AvrLm6. Mol. Plant Microbe Interact. 20, 459-470. doi: 10.1094/MPMI-20-4-0459 
Garnica, D. P., Nemri, A., Upadhyaya, N. M., Rathen, J. P., and Dodds, P. N. (2014). The ins and outs of rust haustoria. PLoS Pathog. 10:e1004329. doi: 10.1371/journal.ppat.1004329

Gawehns, F., Houterman, P. M., Ichou, F. A., Michielse, C. B., Hijdra, M., Cornelissen, B. J. C., et al. (2014). The Fusarium oxysporum effector Six6 contributes to virulence and suppresses I-2-mediated cell death. Mol. Plant Microbe Interact. 27, 336-348. doi: 10.1094/MPMI-11-13-0330-R

Gawehns, F., Ma, L. S., Bruning, O., Houterman, P. M., Boeren, S., Cornelissen, B. J. C., et al. (2015). The effector repertoire of Fusarium oxysporum determines the tomato xylem proteome composition following infection. Front. Plant Sci. 6:967. doi: 10.3389/fpls.2015.00967

Ghanbarnia, K., Fudal, I., Larkan, N. J., Links, M. G., Balesdent, M.-H., Profotova, B., et al. (2015). Rapid identification of the Leptosphaeria maculans avirulence gene AvrLm2 using an intraspecific comparative genomics approach. Mol. Plant Pathol. 16, 699-709. doi: 10.1111/mpp.12228

Ghanbarnia, K., Lydiate, D. J., Rimmer, S. R., Li, G., Kutcher, H. R., Larkan, N. J., et al. (2012). Genetic mapping of the Leptosphaeria maculans avirulence gene corresponding to the LepR1 resistance gene of Brassica napus. TAG. Theor. Appl. Genet. 124, 505-513. doi: 10.1007/s00122-011-1724-3

Gilroy, E. M., Breen, S., Whisson, S. C., Squires, J., Hein, I., Kaczmarek, M., et al. (2011b). Presence/absence, differential expression and sequence polymorphisms between PiAVR2 and PiAVR2-like in Phytophthora infestans determine virulence on R2 plants. New Phytol. 191, 763-776. doi: 10.1111/j.1469-8137.2011.03736.x

Gilroy, E. M., Taylor, R. M., Hein, I., Boevink, P., Sadanandom, A., and Birch, P. R. J. (2011a). CMPG1-dependent cell death follows perception of diverse pathogen elicitors at the host plasma membrane and is suppressed by Phytophthora infestans RXLR effector AVR3a. New Phytol. 190, 653-666. doi: 10.1111/j.14698137.2011.03643.x

Giraldo, M. C., and Valent, B. (2013). Filamentous plant pathogen effectors in action. Nat. Rev. Microbiol. 11, 800-814. doi: 10.1038/nrmicro3119

Giraldo, M. C., Dagdas, Y. F., Gupta, Y. K., Mentlak, T. A., Yi, M., Martinez-Rocha, A. L., et al. (2013). Two distinct secretion systems facilitate tissue invasion by the rice blast fungus Magnaporthe oryzae. Nat. Commun. 4, 1996. doi: $10.1038 /$ ncomms 2996

Godfrey, D., Bohlenius, H., Pedersen, C., Zhang, Z., Emmersen, J., and ThordalChristensen, H. (2010). Powdery mildew fungal effector candidates share N-terminal Y/F/WxC-motif. BMC Genomics 11:317. doi: 10.1186/1471-216 4-11-317

Gomez-Gomez, L., and Boller, T. (2002). Flagellin perception: a paradigm for innate immunity. Trends Plant Sci. 7, 251-256. doi: 10.1016/S13601385(02)02261-6

Gonzalez-Fernandez, R. Q., Prats, E., and Jorrin-Novo, J. V. (2010). Proteomics of plant pathogenic fungi. J. Biomed. Biotech. 2010, 1-36. doi: $10.1155 / 2010 / 932527$

Goritschnig, S., Steinbrenner, A. D., Grunwald, D. J., and Staskawicz, B. J. (2016). Structurally distinct Arabidopsis thaliana NLR immune receptors recognize tandem WY domains of an oomycete effector. New Phytol. 210, 984-996. doi: 10.1111/nph.13823

Gout, L., Fudal, I., Kuhn, M. L., Blaise, F., Eckert, M., Cattolico, L., et al. (2006). Lost in the middle of nowhere: the AvrLm1 avirulence gene of the Dothideomycete Leptosphaeria maculans. Mol. Microbiol. 60, 67-80. doi: 10.1111/j.1365-2958.2006.05076.x

Gout, L., Kuhn, M. L., Vincenot, L., Bernard-Samain, S., Cattolico, L., Barbetti, M., et al. (2007). Genome structure impacts molecular evolution at the AvrLm1 avirulence locus of the plant pathogen Leptosphaeria maculans. Environ. Microbiol. 9, 2978-2992. doi: 10.1111/j.1462-2920.2007.01408.x

Grewal, T. S., Rossnagel, B. G., Bakkeren, G., and Scoles, G. J. (2008). Identification of resistance genes to barley covered smut and mapping of the Ruhl gene using Ustilago hordei strains with defined avirulence genes. Can. J. Plant Pathol. 30, 277-284. doi: 10.1080/07060661.2008.10540543

Gururania, M. A., Venkatesh, J., Upadhyaya, C. P., Nookaraju, A., Pandey, S. K., and Park, S. W. (2012). Plant disease resistance genes: current status and future directions. Physiol. Mol. Plant Pathol. 78, 51-65. doi: 10.1016/j.pmpp.2012.01.002

Guttman, D. S., McHardy, A. C., and Schulze-Lefert, P. (2014). Microbial genomeenabled insights into plant-microorganism interactions. Nat. Rev. 15, 797-813. doi: $10.1038 / \operatorname{nrg} 3748$
Guyon, K., Balague, C., Roby, D., and Raffaele, S. (2014). Secretome analysis reveals effector candidates associated with broad host range necrotrophy in the fungal plant pathogen Sclerotinia sclerotiorum. BMC genomics 15:336. doi: 10.1186/1471-2164-15-336

Haas, B. J., Kamoun, S., Zody, M. C., Jiang, R. H., Handsaker, R. E., Cano, L. M., et al. (2009). Genome sequence and analysis of the Irish potato famine pathogen Phytophthora infestans. Nature 461, 393-398. doi: 10.1038/nature08358

Harrison, M. J. (1998). Biotrophic interface and nutrient transport in plant/fungal symbioses. J. Exp. Biol. 50, 1013-1022.

Hemetsberger, C., Herrberger, C., Zechmann, B., Hillmer, M., and Doehlemann, G. (2012). The Ustilago maydis effector Pep1 suppresses plant immunity by inhibition of host peroxidase activity. PLoS Pathog. 8:e1002684. doi: 10.1371/journal.ppat.1002684

Hof, A., Zechmann, B., Schwammbach, D., Huckelhoven, R., and Doehlemann, G. (2014). Alternative cell death mechanisms determine epidermal resistance in incompatible barley-Ustilago interactions. Mol. Plant Microbe Interact. 27, 403-414. doi: 10.1094/MPMI-10-13-0317-R

Houterman, P. M., Cornelissen, B. J., and Rep, M. (2008). Suppression of plant resistance gene-based immunity by a fungal effector. PLoS Pathog. 4:e1000061. doi: 10.1371/journal.ppat.1000061

Houterman, P. M., Ma, L., van Ooijen, G., de Vroomen, M. J., Cornelissen, B. J., Takken, F. L., et al. (2009). The effector protein Avr2 of the xylemcolonizing fungus Fusarium oxysporum activates the tomato resistance protein I-2 intracellularly. Plant J. 58, 970-978. doi: 10.1111/j.1365-313X.2009.03838.x

Jiang, R. H., Tripathy, S., Govers, F., and Tyler, B. M. (2008). RXLR effector reservoir in two Phytophthora species is dominated by a single rapidly evolving superfamily with more than 700 members. Proc. Natl. Acad. Sci. U.S.A. 105, 4874-4879. doi: 10.1073/pnas.0709303105

Jiang, W., Bikard, D., Cox, D., Zhang, F., and Marraffini, L. A. (2013). RNA-guided editing of bacterial genomes using CRISPR-Cas systems. Nat. Biotechnol. 31, 233-239. doi: 10.1038/nbt.2508

Jinek, M., Chylinski, K., Fonfara, I., Hauer, M., Doudna, J. A., and Charpentier, E. (2012). A programmable dual-RNA-guided DNA endonuclease in adaptive bacterial immunity. Science (New York, N.Y.) 337, 816-821. doi: $10.1126 /$ science. 1225829

Jones, J. D., and Dangl, J. L. (2006). The plant immune system. Nature 444, 323-329. doi: 10.1038/nature05286

Joosten, M. H. A. J., Cozijnsen, T. J., and de Wit, P. J. G. M. (1994). Host resistance to a fungal tomato pathogen lost by a single base-pair change in an avirulence gene. Nature 367, 384-386. doi: 10.1038/367384a0

Kaku, H., Nishizawa, Y., Ishii-Minami, N., Akimoto-Tomiyama, C., Dohmae, N., Takio, K., et al. (2006). Plant cells recognize chitin fragments for defense signaling through a plasma membrane receptor. Proc. Natl. Acad. Sci. U.S.A. 103, 11086-11091. doi: 10.1073/pnas.0508882103

Kale, S. D., Gu, B., Capelluto, D. G. S., Dou, D., Feldman, E., Rumore, A., et al. (2010). External Lipid PI3P mediates entry of eukaryotic pathogen effectors into plant and animal host cells. Cell 142, 284-295. doi: 10.1016/j.cell.2010.06.008

Kamoun, S. (2006). A catalogue of the effector secretome of plant pathogenic oomycetes. Ann. Rev. Phytopathol. 44, 41-60. doi: 10.1146/annurev.phyto.44.070505.143436

Kamoun, S. (2007). Groovy times: filamentous pathogen effectors revealed. Curr. Opin. in Plant Biol. 10, 358-365. doi: 10.1016/j.pbi.2007. 04.017

Kamoun, S., Klucher, K. M., Coffey, M. D., and Tyler, B. M. (1993). A gene encoding a host-specific elicitor protein of Phytophthora parasitica. Mol. Plant Microb. Interact. 6, 573-581. doi: 10.1094/MPMI-6-573

Kamper, J., Kahmann, R., Bolker, M., Ma, L. J., Brefort, T., Saville, B. J., et al. (2006). Insights from the genome of the biotrophic fungal plant pathogen Ustilago maydis. Nature 444, 97-101. doi: 10.1038/nature05248

Kelley, B. S., Lee, S. J., Damasceno, C. M., Chakravarthy, S., Kim, B. D., Martin, G. B., et al. (2010). A secreted effector protein (SNE1) from Phytophthora infestans is a broadly acting suppressor of programmed cell death. Plant J. 62, 357-366. doi: 10.1111/j.1365-313X.2010.04160.x

Kemen, E., Kemen, A. C., Rafiqi, M., Hempel, U., Mendgen, K., Hahn, M., et al. (2005). Identification of a protein from rust fungi transferred from haustoria into infected plant cells. Mol. Plant Microbe Interact. 18, 1130-1139. doi: 10.1094/MPMI-18-1130 
Kerppola, T. K. (2008). Bimolecular fluorescence complementation (BiFC) analysis as a probe of protein interactions in living cells. Annu. Rev. Biophys. 37, 465-487. doi: 10.1146/annurev.biophys.37.032807.125842

Khang, C. H., Berruyer, R., Giraldo, M. C., Kankanala, P., Park, S.-Y., Czymmek, K., et al. (2010). Translocation of Magnaporthe oryzae effectors into rice cells and their subsequent cell-to-cell movement. Plant Cell 22, 1388-1403. doi: $10.1105 /$ tpc. 109.069666

Khang, C. H., Sweigard, J. A., and Valent, B. (1995). The PWL host specificity gene family in the blast fungus Magnaporthe oryzae. Mol. Plant Microbe Interact. 8, 939-948. doi: 10.1094/MPMI-8-0939

Khrunyk, Y., Munch, K., Schipper, K., Lupas, A. N., and Kahmann, R. (2010). The use of FLP-mediated recombination for the functional analysis of an effector gene family in the biotrophic smut fungus Ustilago maydis. New Phytol 187, 957-968. doi: 10.1111/j.1469-8137.2010.03413.x

Kodama, Y., and Hu, C.-D. (2012). Bimolecular fluorescence complementation (BiFC): a 5-year update and future perspectives. Biotechniques 53, 285-298. doi: $10.2144 / 000113943$

Koeck, M., Hardham, A. R., and Dodds, P. N. (2011). The role of effectors of biotrophic and hemibiotrophic fungi in infection. Cell. Microbiol. 13, 1849-1857. doi: 10.1111/j.1462-5822.2011.01665.x

Larkan, N. J., Lydiate, D. J., Parkin, I. A. P., Nelson, M. N., Epp, D. J., Cowling, W. A., et al. (2013). The Brassica napus blackleg resistance LepR3 enclodes a receptor-like protein triggered by the Leptosphaeria maculans effector AVRLM1. New Phytol. 197, 595-607. doi: 10.1111/nph.12043

Lauge, R., Goodwin, P. H., de Wit, P. J., and Joosten, M. H. (2000). Specific HRassociated recognition of secreted proteins from Cladosporium fulvum occurs in both host and non-host plants. Plant J. 23, 735-745. doi: 10.1046/j.1365313x.2000.00843.x

Lauge, R., Joosten, M. H., Van Den Ackerveken, G. F., Van Den Broek, H. W., and De Wit, P. J. (1997). The in planta produced extracellular proteins ECP1 and ECP2 of Cladosporium fulvum are virulence factors. Mol. Plant Microbe Interact. 10, 725-734. doi: 10.1094/MPMI.1997.10.6.725

Lawrence, G. J., Dodds, P. N., and Ellis, J. G. (2010). Transformation of the flax rust fungus, Melampsora lini: selection via silencing of an avirulence gene. Plant J. 61, 364-369. doi: 10.1111/j.1365-313X.2009.04052.x

Li, W., Wang, B., Wu, J., Lu, G., Hu, Y., Zhang, X., et al. (2009). The Magnaporthe oryzae avirulence gene AvrPiz-t encodes a predicted secreted protein that triggers the immunity in rice mediated by the blast resistance gene Piz-t. Mol. Plant Microbe Interact. 22, 411-420. doi: 10.1094/MPMI-22-4-0411

Lievens, B., Houterman, P. M., and Rep, M. (2009).Effector gene screening allows unambiguous identification of Fusarium oxysporum f.sp. lycopersici races and discrimination from other formae speciales. FEMS Microbiol. Lett. 300, 201-215. doi: 10.1111/j.1574-6968.2009.01783.x

Liu, R., Chen, L., Jiang, Y., Zhou, Z., and Zou, G. (2015). Efficient genome editing in filamentous fungus Trichoderma reesei using the CRISPR/CAS9 system. Cell Discov. 1, 1-11. doi: 10.1038/celldisc.2015.7

Liu, T. L., Ye, W. W., Ru, Y. Y., Yang, X. Y., Gu, B., Tao, K., et al. (2011). Two host cytoplasmic effectors are required for pathogenesis of Phytophthora sojae by suppression of host defenses. Plant Physiol. 155, 490-501. doi: $10.1104 / \mathrm{pp} .110 .166470$

Liu, T., Liu, Z., Song, C., Hu, Y., Han, Z., She, J., et al. (2012). Chitin-induced dimerization activates a plant immune receptor. Science (New York, N.Y.) 336, 1160-1164. doi: 10.1126/science. 1218867

Lo Presti, L., Lanver, D., Schweizer, G., Tanaka, S., Liang, L., Tollot, M., et al. (2015). Fungal effectors and plant susceptibility. Annu. Rev. Plant Biol. 66, 513-545. doi: 10.1146/annurev-arplant-043014-114623

Lokossou, A. A., Park, T.- H., Arkel, G. V., Arens, M., Ruyter-Spira, C., Morales, J., et al. (2009). Exploiting knowledge of R/Avr genes to rapidly clone a new LZNBS-LRR family of late blight resistance genes from potato linkage group IV. Mol. Plant Microbe Interact. 22, 630-641. doi: 10.1094/MPMI-22-6-0630

Ma, L. J., van der Does, H. C., Borkovich, K. A., Coleman, J. J., Daboussi, M. J., Di Pietro, A., et al. (2010). Comparative genomics reveals mobile pathogenicity chromosomes in Fusarium. Nature 464, 367-373. doi: 10.1038/nature08850

Ma, L., Houterman, P. M., Gawehns, F., Cao, L., Sillo, F., Richter, H., et al. (2015). The AVR2-SIX5 gene pair is required to activate I-2-mediated immunity in tomato. New Phytol. 208, 507-518. doi: 10.1111/nph.13455

Macho, A. P., and Zipfel, C. (2014). Plant PRRs and the activation of innate immune signaling. Mol. Cell 54, 263-272. doi: 10.1016/j.molcel.2014.03.028
Mackie, A. J., Roberts, A. M., Callow, J. A., and Green, J. R. (1991). Molecular differentiation in pea powdery-mildew haustoria. Planta. 183, 399-408. doi: 10.1007/BF00197739

Manners, J. M., and Gay, J. L. (1983). "The host-parasite interface and nutrient transfer in biotrophic parasitism," in Biochemical Plant Pathoglogy, ed J. A. Callow (Chichester: John Wiley and Sons Ltd.), 163-168.

Manning, V. A., Hamilton, S. M., Karplus, P. A., and Ciuffetti, L. M. (2008), The Arg-Gly-Asp-containing, solvent-exposed loop of Ptr ToxA is required for internalization. Mol. Plant Microbe Interact. 21, 315-325. doi: 10.1094/MPMI21-3-0315

Matsu-ura, T., Baek, M., Kwon, J., and Hong, C. (2015). Efficient gene editing in Neurospora crassa with CRISPR/CAS9 technology. Fungal Biol. Biotechnol. 2, 1-7. doi: 10.1186/s40694-015-0015-1

Mentlak, T. A., Kombrink, A., Shinya, T., Ryder, L. S., Otomo, I., Saitoh, H., et al. (2012). Effector-mediated suppression of chitin-triggered immunity by Magnaporthe oryzae is necessary for rice blast disease. Plant Cell 24, 322-335. doi: $10.1105 /$ tpc. 111.092957

Miya, A., Albert, P., Shinya, T., Desaki, Y., Ichimura, K., Shirasu, K., et al. (2007). CERK1, a LysM receptor kinase, is essential for chitin elicitor signaling in Arabidopsis. Proc. Natl. Acad. Sci. U.S.A. 104, 19613-19618. doi: 10.1073/pnas.0705147104

Mosquera, G., Giraldo, M. C., Khang, C. H., Coughlan, S., and Valent, B. (2009). Interaction transcriptome analysis identifies Magnaporthe oryzae BAS1-4 as biotrophy-associated secreted proteins in rice blast disease. Plant Cell 21, 1273-1290. doi: 10.1105/tpc.107.055228

Mueller, A. N., Ziemann, S., Treitschke, S., Assmann, D., and Doehlemann, G. (2013). Compatibility in the Ustilago maydis -maize interaction requires inhibition of host cysteine proteases by the fungal effector Pit2. PLoS Pathog. 9:e1003177. doi: 10.1371/journal.ppat.1003177

Na, R., Yu, D., Qutob, D., Zhao, J., and Gijzen, M. (2013). Deletion of the Phytophthora sojae avirulence gene Avrld causes gain of viruence on Rpsld. Mol. Plant Microbe Interact. 16, 969-976. doi: 10.1094/MPMI-02-13-0036-R

Nemri, A., Saunders, D. G., Anderson, C., Upadhyaya, N. M., Win, J., Lawrence, G. J., et al. (2014). The genome sequence and effector complement of the flax rust pathogen Melampsora lini. Front. Plant Sci. 5:98. doi: 10.3389/fpls.2014.00098

Newman, M.-A., Sundelin, T., Nielsen, J. T., and Erbs, G. (2013). MAMP (microbeassociated molecular pattern) triggered immunity in plants. Front. Plant Sci. 4:139. doi: $10.3389 /$ fpls.2013.00139

Nirmala, J., Drader, T., Lawrence, P. K., Yin, C., Hulbert, S., Steber, C. M., et al. (2011). Concerted action of two avirulent spore effectors activates reaction to Puccinia graminis $1(\mathrm{Rpg} 1)$-mediated cereal stem rust resistance. Proc. Natl. Acad. Sci. U.S.A. 108, 14676-14681. doi: 10.1073/pnas.11117 71108

Nissim, L., Perli, S. D., Fridkin, A., Perez-Pinera, P., and Lu, T. K. (2014). Multiplexed and programmable regulation of gene networks with an integrated RNA and CRISPR/Cas toolkit in human cells. Mol. Cell 54, 698-710. doi: 10.1016/j.molcel.2014.04.022

Nodvig, C. S., Nielsen, J. B., Kogle, M. E., and Mortensen, U. H. (2015). A CRISPR-Cas9 system for genetic engineering of filamentous fungi. PLoS One 10:e0133085. doi: 10.1371/journal.pone.0133085

Nováková, M., Šašek, V., Trdá, L., Krutinová, H., Mongin, T., Valentová, O., et al. (2015). Leptosphaeria maculans effector AvrLm4-7 affects SA- and ETsignalling and $\mathrm{H}_{2} \mathrm{O}_{2}$ accumulation in Brassica napus. Mol. Plant Pathol. doi: 10.1111/mpp.12332. [Epub ahead of print].

Oerke, E. C. (2006). Crop losses to pests. J. Agric. Sci. 144, 31-43. doi: $10.1017 / \mathrm{S} 0021859605005708$

Oh, S. K., Young, C., Lee, M., Oliva, R., Bozkurt, T. O., Cano, L. M., et al. (2009). In planta expression screens of Phytophthora infestans RXLR effectors reveal diverse phenotypes, including activation of the Solanum bulbocastanum disease resistance protein Rpi-blb2. Plant Cell 21, 2928-2947. doi: $10.1105 /$ tpc. 109.068247

Orbach, M. J., Farrall, L., Sweigard, J. A., Chumley, F. G., and Valent, B. (2000). A telomeric avirulence gene determines efficacy for the rice blast resistance gene Pi-ta. Plant Cell 12, 2019-2032. doi: 10.1105/tpc.12.11.2019

Panwar, V., McCallum, B., and Bakkeren, G. (2013). Endogenous silencing of Puccinia triticina pathogenicity genes through in planta-expressed sequences leads to the suppression of rust diseases on wheat. Plant J. 73, 521-532. doi: $10.1111 /$ tpj.12047 
Park, C. H., Chen, S., Shirsekar, G., Zhou, B., Khang, C. H., Songkumarn, P., et al. (2012). The Magnaporthe oryzae effector AvrPiz-t targets the RING E3 ubiquitin ligase APIP6 to suppress pathogen-associated molecular pattern-triggered immunity in rice. Plant Cell 24, 4748-4762. doi: 10.1105/tpc.112.105429

Parlange, F., Daverdin, G., Fudal, I., Kuhn, M. L., Balesdent, M. H., Blaise, F., et al. (2009). Leptosphaeria maculans avirulence gene AvrLm4-7 confers a dual recognition specificity by the $\mathrm{R} \operatorname{lm} 4$ and $\mathrm{Rlm} 7$ resistance genes of oilseed rape, and circumvents Rlm4-mediated recognition through a single amino acid change. Mol. Microbiol. 71, 851-863. doi: 10.1111/j.1365-2958.2008.06547.x

Petre, B., and Kamoun, S. (2014). How do filamentous pathogens deliver effector proteins into plant cells? PLoS Biol. 12:e1001801. doi: 10.1371/journal.pbio.1001801

Petre, B., Joly, D. L., and Duplessis, S. (2014). Effector proteins of rust fungi. Front. Plant Sci. 5:416. doi: 10.3389/fpls.2014.00416

Pieterse, C. M. J., Van West, P., Verbakel, H. M., Brasse, P. W. H. M., Van Den BergVelthuis, G. C. M., and Govers, F. (1994). Structure and genomic organization of the ipiB and ipiO gene clusters of Phytophthora infestans. Gene 138, 67-77. doi: 10.1016/0378-1119(94)90784-6

Plissonneau, C., Daverdin, G., Ollivier, B., Blaise, B., Degrave, A., Fudal, I., et al. (2016). A game of hide and seek between avirulence genes AvrLm47 and AvrLm3 in Leptosphaeria maculans. New Phytol. 209, 1613-1624. doi: 10.1111/nph.13736

Qutob, D., Kemmerling, B., Brunner, F., Kufner, I., Engelhardt, S., Gust, A. A., et al. (2006). Phytotoxicity and innate immune responses induced by Nep1-like proteins. Plant Cell 18, 3721-3724. doi: 10.1105/tpc.106.044180

Qutob, D., Tedman-Jones, J., Dong, S., Kuflu, K., Pham, H., Wang, Y., et al. (2009). Copy number variation and transcriptional polymorphisms of Phytophthora sojae RXLR Effector Genes Avrla and Avr3a. PLoS One 4:e5066. doi: 10.1371/annotation/2a2adcf8-afbc-4d46-92c6-d543d6b29182

Raffaele, S., and Kamoun, S. (2012). Genome evolution in filamentous plant pathogens: why bigger can be better. Nat. Rev. Microbiol. 10, 417-430. doi: $10.1038 /$ nrmicro2790

Rafiqi, M., Gan, P. H., Ravensdale, M., Lawrence, G. J., Ellis, J. G., Jones, D. A., et al. (2010). Internalization of flax rust avirulence proteins into flax and tobacco cells can occur in the absence of the pathogen. Plant Cell 22, 2017-2032. doi: 10.1105/tpc. 109.072983

Ravid, T., and Hochstrasser, M. (2008). Diversity of degradation signals in the ubiquitin-proteasome system. Nat. Rev. Mol. Cell Biol. 9, 679-690. doi: $10.1038 / \mathrm{nrm} 2468$

Redkar, A., Hoser, R., Schilling, L., Zechmann, B., Krzymowska, M., Walbot, V., et al. (2015). Secreted effector protein of Ustilago maydis guides maize leaf cells to form tumors. Plant Cell 27, 1332-1351. doi: 10.1105/tpc.114.131086

Rep, M., van der Does, H. C., Meijer, M., van Wijk, R., Houterman, P. M., Dekker, H. L., et al. (2004). A small, cysteine-rich protein secreted by Fusarium oxysporum during colonization of xylem vessels is required for I-3-mediated resistance in tomato. Mol. Microbiol. 53, 1373-1383. doi: 10.1111/j.13652958.2004.04177.x

Ricci, P., Bonnet, P., Huet, J.-C., Sallantin, M., Beauvais-Cante, F., Bruneteau, M., et al. (1989). Structure and activity of proteins from pathogenic fungi Phytophthora eliciting necrosis and acquired resistance in tobacco. Eur. J. Biochem. 183, 555-563. doi: 10.1111/j.1432-1033.1989.tb21084.x

Ridout, C. J., Skamnioti, P., Porritt, O., Sacristan, S., Jones, J. D., and Brown, J. K. (2006). Multiple avirulence paralogues in cereal powdery mildew fungi may contribute to parasite fitness and defeat of plant resistance. Plant Cell 18, 2402-2414. doi: 10.1105/tpc.106.043307

Rose, J. K., Ham, K. S., Darvill, A. G., and Albersheim, P. (2002). Molecular cloning and characterization of glucanase inhibitor proteins: coevolution of a counterdefense mechanism by plant pathogens. Plant Cell 14, 1329-1345. doi: 10.1105/tpc.002253

Rouxel, T., Grandaubert, J., Hane, J. K., Hoede, C., van de Wouw, A. P., Couloux, A., et al. (2011). Effector diversification within compartments of the Leptosphaeria maculans genome affected by Repeat-Induced Point mutations. Nat. Commun. 2, 202. doi: 10.1038/ncomms1189

Sanchez-Vallet, A., Saleem-Batcha, R., Kombrink, A., Hansen, G., Valkenburg, D. J., Thomma, B. P., et al. (2013). Fungal effector Ecp6 outcompetes host immune receptor for chitin binding through intrachain LysM dimerization. Elife 2:e00790. doi: 10.7554/eLife.00790
Sander, J. D., and Joung, J. K. (2014). CRISPR-Cas systems for editing, regulating and targeting genomes. Nat. Biotechnol. 32, 347-355. doi: 10.1038/nb t. 2842

Šašek, V., Nováková, M., Jindřichová, B., Bóka, K., Valentová, O., and Burketová, L. (2012). Recognition of avirulence gene AvrLm1 from hemibiotrophic ascomycete Leptosphaeria maculans triggers salicylic acid and ethylene signaling in Brassica napus. Mol. Plant Microbe Interact. 25, 1238-1250. doi: 10.1094/MPMI-02-12-0033-R

Saunders, D. G., Win, J., Cano, L. M., Szabo, L. J., Kamoun, S., and Raffaele, S. (2012). Using hierarchical clustering of secreted protein families to classify and rank candidate effectors of rust fungi. PLoS One 7:e29847. doi: 10.1371/journal.pone.0029847

Schirawski, J., Mannhaupt, G., Munch, K., Brefort, T., Schipper, K., Doehlemann, G., et al. (2010). Pathogenicity determinants in smut fungi revealed by genome comparison. Science (New York, N.Y.) 330, 1546-1548. doi: $10.1126 /$ science. 1195330

Schmidt, S. M., Houterman, P. M., Schreiver, I., Ma, L., Amyotte, S., Chellappan, B., et al. (2013). MITEs in the promoters of effector genes allow prediction of nove lvirulence genes in Fusariumoxysporum. BMC Genomics 14:119. doi: 10.1186/1471-2164-14-119

Schornack, S., van Damme, M., Bozkurt, T. O., Cano, L. M., Smoker, M., Thines, M., et al. (2010). Ancient class of translocated oomycete effectors targets the host nucleus. Proc. Natl. Acad. Sci. U.S.A. 107, 17421-17426. doi: 10.1073/pnas.1008491107

Schottens-Toma, I. M. J., and DeWit, P. J. (1988). Purification and primary structure of a necrosis-inducing peptide from the apoplastic fluids of tomato infected with Cladosporium fulvum (syn. Fulvia fulva). Physiol. Mol. Plant Pathol. 33, 59-67. doi: 10.1016/0885-5765(88)90043-4

Schwessinger, B., and Ronald, P. C. (2012). Plant Innate immunity: perception of conserved microbial signatures. Ann. Rev. Plant Biol. 63, 451-482. doi: 10.1146/annurev-arplant-042811-105518

Schwessinger, B., Bart, R., Krasileva, K. V., and Coaker, G. (2015). Focus issue on plant immunity: from model systems to crop species. Front. Plant Sci. 6:195. doi: 10.3389/fpls.2015.00195

Senchou, V., Weide, R., Carrasco, A., Bouyssou, H., Pont-Lezica, R., Govers, F., et al. (2004). High affinity recognition of aPhytophthora protein by Arabidopsis via an RGD motif. Cell. Mol. Life Sci. 61, 502-509. doi: 10.1007/s00018-0033394-Z

Shan, W., Cao, M., Leung, D., and Tyler, B. M. (2004). The Avrlb locus of Phytophthora sojae encodes an elicitor and a regulator required for avirulence on soybean plants carrying resistance gene Rps1b. Mol. Plant Microbe Interact. 17, 394-403. doi: 10.1094/MPMI.2004.17.4.394

Shen, Q. H., Saijo, Y., Mauch, S., Biskup, C., Bieri, S., Keller, B., et al. (2007). Nuclear activity of MLA immune receptors links isolate-specific and basal disease-resistance responses. Science 315, 1098-1103. doi: $10.1126 /$ science. 1136372

Shimizu, T., Nakano, T., Takamizawa, D., Desaki, Y., Ishii-Minami, N., Nishizawa, Y., et al. (2010). Two LysM receptor molecules, CEBiP and OsCERK1, cooperatively regulate chitin elicitor signaling in rice. Plant J. 64, 204-214. doi: 10.1111/j.1365-313X.2010.04324.X

Shinya, T., Motoyama, N., Ikeda, A., Wada, M., Kamiya, K., Hayafune, M., et al. (2012). Functional characterization of CEBiP and CERK1 homologs in Arabidopsis and rice reveals the presence of different chitin receptor systems in plants. Plant Cell Physiol. 53, 1696-1706. doi: 10.1093/pcp/ pcs 113

Shirasu, K. (2009). The HSP90-SGT1 chaperone complex for NLR immune sensors. Annu. Rev. Plant Biol. 60, 139-164. doi: 10.1146/annurev.arplant.59.032607.092906

Saitoh, H., Fujisawa, S., Mitsuoka, C., Ito, A., Hirabuchi, A., Ikeda, K., et al. (2012). Large-scale gene disruption in Magnaporthe oryzae identifies MC69, a secreted protein required for infection by monocot and dicot fungal pathogens. PLoS Pathog. 8:e1002711. doi: 10.1371/journal.ppat.1002711

Song, J., Win, J., Tian, M., Schornack, S., Kaschani, F., Ilyas, M., et al. (2009). Apoplastic effectors secreted by two unrelated eukaryotic plant pathogens target the tomato defense protease Rcr3. Proc. Natl. Acad. Sci. U.S.A. 106, 1654-1659. doi: 10.1073/pnas.0809201106

Soyer, J. L., El Ghalid, M., Glaser, N., Ollivier, B., Linglin, J., Grandaubert, J., et al. (2014). Epigenetic control of effector gene expression in the plant 
pathogenic fungus Leptosphaeria maculans. PLoS Genet. 10:e1004227. doi: 10.1371/journal.pgen.1004227

Sperschneider, J., Dodds, P. N., Gardiner, D. M., Manners, J. M., Singh, K. B., and Taylor, J. M. (2015a). Advances and challenges in computational prediction of effectors from plant pathogenic fungi. PLoS Pathog. 11:e1004806. doi: 10.1371/journal.ppat.1004806

Sperschneider, J., Gardiner, D. M., Dodds, P. N., Tini, F., Covarelli, L., Singh, K. B., et al. (2015b). EffectorP: predicting fungal effector proteins from secretomes using machine learning. New Phytol. 210, 743-761. doi: 10.1111/nph. 13794

Spoel, S. H., Mou, Z., Tada, Y., Spivey, N. W., Genschik, P., and Dong, X. (2009). Proteasome-mediated turnover of the transcription coactivator NPR1 plays dual roles in regulating plant immunity. Cell 137, 860-872. doi: 10.1016/j.cell.2009.03.038

Stergiopoulos, I., and de Wit, P. J. (2009). Fungal effector proteins. Ann. Rev. Phytopathol. 47, 233-263. doi: 10.1146/annurev.phyto.112408.132637

Stotz, H. U., Mitrousia, G. K., de Wit, P. J., and Fitt, B. D. (2014). Effector-triggered defence against apoplastic fungal pathogens. Trends Plant Sci. 19, 491-500. doi: 10.1016/j.tplants.2014.04.009

Sweigard, J. A., Carroll, A. M., Kang, S., Farral, L., Chumely, F. G., and Valent, B. (1995). Identification, cloning and characterization of PWL2, a gene for host-species specificity in the rice blast fungus. Plant Cell 7, 1221-1233. doi: 10.1105/tpc.7.8.1221

Tanaka, S., Brefort, T., Neidig, N., Djamei, A., Kahnt, J., Vermerris, W., et al. (2014). A secreted Ustilago maydis effector promotes virulence by targeting anthocyanin biosynthesis in maize. eLife 3:e01355. doi: 10.7554/eLife.01355

Tian, M., Benedetti, B., and Kamoun, S. (2005). A second Kazal-like protease inhibitor from Phytophthora infestans inhibits and interacts with the apoplastic pathogenesis-related protease P69B of tomato. Plant Physiol. 138, 1785-1793. doi: $10.1104 /$ pp. 105.061226

Tian, M., Huitema, E., Da Cunha, L., Torto-Alalibo, T., and Kamoun, S. (2004). A Kazal-like extracellular serine protease inhibitor from Phytophthora infestans targets the tomato pathogenesis-related protease P69B. J. Biol. Chem. 279, 26370-26377. doi: 10.1074/jbc.M400941200

Tian, M., Win, J., Song, J., van der Hoorn, R., van der Knaap, E., and Kamoun, S. (2007). A Phytophthora infestans cystatin-like protein targets a novel tomato papain-like apoplastic protease. Plant Physiol. 143, 364-377. doi: 10.1104/pp.106.090050

Tyler, B. M., and Rouxel, T. (2013). Effectors of Fungi and Oomycetes: Their Virulence and Avirulence Functions and Translocation from Pathogen to HOST Cells. Ames, IA: John Wiley and Sons, Inc.

Tyler, B. M., Tripathy, S., Zhang, X., Dehal, P., Jiang, R. H., Aerts, A., et al. (2006). Phytophthora genome sequences uncover evolutionary origins and mechanisms of pathogenesis. Science (New York, N.Y.) 313, 1261-1266. doi: $10.1126 /$ science. 1128796

Upadhyaya, N. M., Mago, R., Staskawicz, B. J., Ayliffe, M. A., Ellis, J. G., and Dodds, P. N. (2014). A bacterial type III secretion assay for delivery of fungal effector proteins into wheat. Mol. Plant Microbe Interact. 27 255-264. doi: 10.1094/mpmi-07-13-0187-fi

Van de Wouw, A. P., Lowe, R. G., Elliott, C. E., Dubois, D. J., and Howlett, B. J. (2014). An avirulence gene, AvrLmJ1, from the blackleg fungus, Leptosphaeria maculans, confers avirulence to Brassica juncea cultivars. Mol. Plant Pathol. 15, 523-530. doi: 10.1111/mpp.12105

Van de Wouw, A. P., Stonard, J. F., Howlett, B. J., West, J. S., Fitt, B. D. L., and Atkins, S. D. (2010). Determining frequencies of avirulent alleles in airborne Leptosphaeria maculans inoculum using quantitative PCR. Plant Pathol. 59, 809-818. doi: 10.1111/j.1365-3059.2010.02311.x

van den Burg, H. A., Harrison, S. J., Joosten, M. H., Vervoort, J., and de Wit, P. J. (2006). Cladosporium fulvum Avr4 protects fungal cell walls against hydrolysis by plant chitinases accumulating during infection. Mol. Plant Microbe Interact.19, 1420-1430. doi: 10.1094/MPMI-191420

van den Hooven, H. W., Van Den Burg, H. A., Vossen, P., Boeren, S., DeWit, P. J. G. M., and Vervoort, J. (2001). Disulfide bond structure of the AVR9 elicitor of the fungal tomato pathogen Cladosporium fulvum: evidence for a cystine knot. Biochemistry 40, 3458-3466. doi: 10.1021/bi0023089

van Esse, H. P., Van't Klooster, J. W., Bolton, M. D., Yadeta, K. A., van Baarlen, P., Boeren, S., et al. (2008). The Cladosporium fulvum virulence protein Avr2 inhibits host proteases required for basal defense. Plant Cell 20, 1948-1963. doi: $10.1105 /$ tpc. 108.059394

van Kan, J. A. L., van den Ackerveken, G. F. J. M., and de Wit, P. J. (1991). Cloning and characterization of cDNA of avirulence gene avr9 of the fungal pathogen Cladosporium fulvum, causal agent of tomato leaf mold. Mol. Plant Microbe Interact. 4, 52-59. doi: 10.1094/MPMI-4-052

van Poppel, P. M. J. A., Guo, J., van de Vondervoort, P. J. I., Jung, M. W. M., Birch, P. R. J., Whisson, S. C., et al. (2008). The Phytophthora infestans avirulence gene Avr4 encodes an RXLR-DEER effector. Mol. Plant Microbe Interact. 21, 1460-1470. doi: 10.1094/MPMI-21-11-1460

van Poppel, P. M., Jiang, R. H., Sliwka, J., and Govers, F. (2009). Recognition of Phytophthora infestans Avr4 by potato R4 is triggered by C-terminal domains comprising W motifs. Mol. Plant Pathol. 10, 611-620. doi: 10.1111/j.13643703.2009.00556.x

Vleeshouwers, V. G., Rietman, H., Krenek, P., Champouret, N., Young, C., Oh, S. K., et al. (2008). Effector genomics accelerates discovery and functional profiling of potato disease resistance and Phytophthora infestans avirulence genes. PLoS One 3:e2875. doi: 10.1371/journal.pone.0002875

Walbot, V., and Skibbe, D. S. (2010). Maize host requirements for Ustilago maydis tumor induction. Sex. Plant Reprod. 2, 1-13. doi: 10.1007/s00497-009-0109-0

Wang, C. I., Guncar, G., Forwood, J. K., Teh, T., Catanzariti, A. M., Lawrence, G. J., et al. (2007). Crystal structures of flax rust avirulence proteins AvrL567-A and -D reveal details of the structural basis for flax disease resistance specificity. Plant Cell 19, 2898-2912. doi: 10.1105/tpc.107.053611

Wang, Q., Han, C., Ferreira, A. O., Yu, X., Ye, W., Tripathy, S., et al. (2011). Transcriptional programming and functional interactions within the Phytophthora sojae RXLR effector repertoire. Plant Cell 23, 2064-2086. doi: 10.1105/tpc.111.086082

Wang, Y. H., and Irving, H. R. (2011). Developing a model for plant hormone interaction. Plant Signal. Behav. 6, 494-500. doi: 10.4161/psb.6.4.14558

Westerink, N., Brandwagt, B. F., de Wit, P. J., and Joosten, M. H. (2004). Cladosporium fulvum circumvents the second functional resistance gene homologue at the Cf-4 locus (Hcr9-4E) by secretion of a stable avr4E isoform. Mol. Microbiol. 54, 533-545. doi: 10.1111/j.1365-2958.2004.04288.x

Whigham, E., Qi, S., Mistry, D., Surana, P., Xu, R., Fuerst, G., et al. (2015). Broadly conserved fungal effector BEC1019 suppresses host cell death and enhances pathogen virulence in powdery mildew of Barley (Hordeum vulgare L.). Mol. Plant Microbe Interact. 28, 968-983. doi: 10.1094/MPMI-02-15-0027-FI

Whisson, S. C., Boevink, P. C., Moleleki, L., Avrova, A. O., Morales, J. G., Gilroy, E. M., et al. (2007). A translocation signal for delivery of oomycete effector proteins into host plant cells. Nature 450, 115-118. doi: 10.1038/nature06203

Win, J., Chaparro-Garcia, A., Belhaj, K., Saunders, D. G., Yoshida, K., Dong, S., et al. (2012). Effector biology of plant-associated organisms: concepts and perspectives. Cold Spring Harb. Symp. Quant. Biol. 77, 235-247. doi: 10.1101/sqb.2012.77.015933

Wirth, D., Gama-Norton, L., Riemer, P., Sandhu, U., Schucht, R., and Hauser, H. (2007). Road to precision: recombinase-based targeting technologies for genome engineering. Curr. Opin. Biotechnol. 18, 411-419. doi: 10.1016/j.copbio.2007.07.013

Xu, S., Chen, J., Liu, L., Wang, X., Huang, X., and Zhai, Y. (2007). Proteomics associated with virulence differentiation of Curvularia lunata in maize in China. J. Integr. Plant Biol. 49, 487-496. doi: 10.1111/j.1744-7909.2007. 00469.x

Yaeno, T., Li, H., Chaparro-Garcia, A., Schornack, S., Koshiba, S., Watanabe, S., et al. (2011). Phosphatidylinositol monophosphate-binding interface in the oomycete RXLR effector AVR3a is required for its stability in host cells to modulate plant immunity. Proc. Natl. Acad. Sci. U.S.A. 108, 14682-14687. doi: $10.1073 /$ pnas. 1106002108

Yin, C., Downey, S. I., Klages-Mundt, N. L., Ramachandran, S., Chen, X., Szabo, L. J., et al. (2015). Identification of promising host-induced silencing targets among genes preferentially transcribed in haustoria of Puccinia. BMC Genomics 16:1791. doi: 10.1186/s12864-015-1791-y

Yin, W., Dong, S., Zhai, L., Lin, Y., Zheng, X., and Wang, Y. (2013). Phytophthora sojae Avrld genes encode an RxLR-DEER effector with presence and absence polymorphisms among pathogen strains. Mol. Plant Microbe Interact. 26, 958-968. doi: 10.1094/MPMI-02-13-0035-R

Yoshida, K., Saitoh, H., Fujisawa, S., Kanzaki, H., Matsumura, H., Yoshida, K., et al. (2009). Association genetics reveals three novel avirulence genes from the 
rice blast fungal pathogen Magnaporthe oryzae. Plant Cell 21, 1573-1591. doi: 10.1105/tpc.109.066324

Zhang, M., Kadota, Y., Prodromou, C., Shirasu, K., and Pearl, L. H. (2010). Structural basis for assembly of Hsp90-Sgt1-CHORD protein complexes: implications for chaperoning of NLR innate immunity receptors. Mol. Cell 39, 269-281. doi: 10.1016/j.molcel.2010.05.010

Zhang, S., and Xu, J. R. (2014). Effectors and effector delivery in Magnaporthe oryzae. PLoS Pathog. 10, e1003826. doi: 10.1371/journal.ppat.1003826

Zhang, Z. M., Zhang, X., Zhou, Z. R., Hu, H. Y., Liu, M., Zhou, B., et al. (2013). Solution structure of the Magnaporthe oryzae avirulence protein AvrPiz-t. J. Biomol. NMR 55, 219-223. doi: 10.1007/s10858-012-9695-5

Zhang, Z., Mao, Y., Ha, S., Liu, W., Botella, J. R., and Zhu, J. K. (2015). A multiplex CRISPR/CAS9 platform for fast and efficient editing of multiple genes in Arabidopsis. Plant Cell Rep. doi: 10.1007/s00299-015-1900-z. [Epub ahead of print].

Zhou, B., Qu, S., Liu, G., Dolan, M., Sakai, H., Lu, G., et al. (2006). The eight amino-acid differences within three leucine-rich repeats between $\mathrm{Pi} 2$ and
Piz-t resistance proteins determine the resistance specificity to Magnaporthe grisea. Mol. Plant Microbe Interact. 19, 1216-1228. doi: 10.1094/MPMI-1 9-1216

Zhu, S., Li, Y., Vossen, J. H., Visser, R. G., and Jacobsen, E. (2012). Functional stacking of three resistance genes against Phytophthora infestans in potato. Transgenic Res. 21, 89-99. doi: 10.1007/s11248-011-9510-1

Conflict of Interest Statement: The authors declare that the research was conducted in the absence of any commercial or financial relationships that could be construed as a potential conflict of interest.

Copyright (c) 2016 Selin, de Kievit, Belmonte and Fernando. This is an open-access article distributed under the terms of the Creative Commons Attribution License (CC $B Y)$. The use, distribution or reproduction in other forums is permitted, provided the original author(s) or licensor are credited and that the original publication in this journal is cited, in accordance with accepted academic practice. No use, distribution or reproduction is permitted which does not comply with these terms. 